Therapeutic Servicescapes and Market-Mediated Performances of Emotional Suffering

\title{
LEIGHANNE HIGGINS
}

KATHY HAMILTON 
Leighanne Higgins (1.higgins@lancaster.ac.uk) is lecturer of marketing at Lancaster University Management School, Lancaster University, Charles Carter Building, Bailrigg, Lancaster, LA1 4YX, UK. Kathy Hamilton (kathy.hamilton@strath.ac.uk) is reader of marketing at Strathclyde Business School, University of Strathclyde, 199 Cathedral Street, Glasgow, Scotland, G4 0QU, UK. The authors are extremely appreciative for the insightful and constructive advice and support offered by the three anonymous reviewers, the associate editor and editor. 
We introduce the concept of therapeutic servicescapes, defined as consumption settings where emplaced, market-mediated performances compensate for socio-cultural dilemmas. Our focus is on the localization of emotions which are emplaced in specific socio-spatial features and collectively reproduced through ritualized consumer performances. This ethnographic study of religious pilgrimage consumption reveals that the therapeutic servicescape comprises three features: evocative spaces, ideological homogeneity and restorative emotion scripts. These servicescape features catalyze the consumer rituals of therapeutic relations, therapeutic release and therapeutic renewal. Our theorization of therapeutic servicescapes offers three contributions. First, we reveal how emotions are socially and geographically orchestrated and transformed in marketplace settings. Second, we demonstrate how therapeutic ritual performances reproduce emplaced, market-mediated emotion and compensate for embodied emotional restrictions. Third, we demonstrate how the negotiation of emotional ordering guides the therapeutic dialogue between religion and the marketplace.

Keywords: servicescapes, consumer emotion, therapeutic consumption, pilgrimage 
Consumer researchers have explored how market-mediated performances can provide relief from socio-cultural dilemmas. Consumers turn to the marketplace to address the alienation inherent in post-industrial, corporate capitalism (Belk and Costa 1998; Canniford and Shankar 2013; Celsi, Rose, and Leigh 1993, Goulding et al. 2009, Scott, Cayla, and Cova 2016), to escape from oppressive urbanization (Arnould and Price 1993; Arnould, Price, and Tierney 1998; Belk and Costa 1998; Canniford and Shankar 2013), and to seek spiritual revitalization (Crockett and Davis 2016; Moisio and Beruchashvili 2010; O'Guinn and Belk 1989; Sherry and Kozinets 2007). Implicit in much of this research is that a diverse range of marketplace contexts can play a compensatory function by orchestrating performances that consumers find therapeutic (Lears 1983). The Oxford Dictionary defines therapeutic as "having a good effect on the body or mind; contributing to a sense of well-being."

In this article, we introduce the concept of therapeutic servicescapes, defined as consumption settings where emplaced, market-mediated performances compensate for sociocultural dilemmas. Our focus is on the localization of emotions which are emplaced in specific socio-spatial features and collectively reproduced through ritualized consumer performances. Prior work recognizes that servicescapes can orchestrate ritualized performances of consumer emotion such as pleasure and happiness (Goulding et al. 2009; O’Guinn and Belk 1989) or fear (Arnould and Price 1993; Canniford and Shankar 2013; Celsi et al. 1993). Emotions emerge through socio-spatial encounters (Conradson 2005; Davidson, Bondi and Smith 2012; Davidson and Milligan 2004), but existing accounts do not fully explain how consumer emotions are socially and geographically orchestrated. Indeed, Moisio and Beruchashvili $(2010,872)$ call for research to better explore how "marketplace arrangements cultivate emotions."

We focus on a therapeutic servicescape that orchestrates performances of emotional suffering. The privileging of emotional suffering is particularly therapeutic (Illouz 2007) and 
compensates for the emotion deficit that is prevalent in Western consumer culture (Furedi 2004). It is thus ideally matched with our intention of building understanding of the localized nature of consumer emotion. Our central goal is to theorize how emplaced, market-mediated performances of emotional suffering become therapeutic. We are guided by the following research questions: what are the socio-spatial features of a therapeutic servicescape? What therapeutic consumer rituals are catalyzed by these servicescape features? Our analysis draws on the concepts of therapeutic landscapes (Gesler 2003) and emotion scripts (Turner and Stets 2006) which enable us to uncover the socio-spatial nature of emotion.

We theorize that the therapeutic servicescape comprises three features: evocative spaces, ideological homogeneity, and restorative emotion scripts. These servicescape features catalyze the consumer rituals of therapeutic relations, therapeutic release and therapeutic renewal. Our theorization of therapeutic servicescapes offers three contributions. First, we reveal how emotions are socially and geographically orchestrated and transformed in marketplace settings. Second, we demonstrate how therapeutic ritual performances reproduce emplaced, market-mediated emotion and compensate for embodied emotional restrictions. Third, our contextual focus on religious pilgrimage demonstrates how the negotiation of emotional ordering guides the therapeutic dialogue between religion and the marketplace.

Our article is structured as follows. We begin with a theoretical review detailing how servicescapes that respond to socio-cultural dilemmas become therapeutic. We then demonstrate how an emotional geography perspective is helpful in theorizing emplaced consumer emotion. The details of a three-year ethnographic study of Lourdes pilgrimage are presented, before we proceed to discuss the therapeutic servicescape features and how these catalyze therapeutic consumer rituals. We finish by discussing our theoretical contributions. 


\section{THEORETICAL FOUNDATIONS}

Introducing Therapeutic Servicescapes

Servicescapes have been defined as the physical built surroundings within consumption settings which influence the nature and quality of social interaction (Bitner 1992). Sherry (1998) suggests that contemporary servicescapes encompass natural and cultural/built environments and physical and ethereal qualities. In this article, we introduce the concept of therapeutic servicescapes, where localized socio-spatial features orchestrate market-mediated performances that compensate for socio-cultural dilemmas. This perspective builds on the idea that therapeutic consumption compensates for the generalized anxieties associated with fluid life settings (Bauman 2007). Therapeutic consumption can be traced to the historical upheaval of the late nineteenth century when consumption began to be viewed as a viable means of escape and compensation for fragmented, troubled selves and spiritual voids (Lears 1983). For Lears (1983), the drivers of therapeutic consumption included an interdependent market economy characterized by bureaucratic corporations that threatened personal autonomy, rising urbanization and technological progress, and a more liberal religious landscape that undermined ethical and moral standards. Lears $(1983,12)$ referred to "abundance therapy" to suggest that consumption unleashed consumers towards fuller lives, intense experiences, and the aspiration of self-realization. However, this abundance therapy merely accelerated the development of consumer culture, promoted a new set of social controls, and ultimately reinforced rationalization.

We suggest that the drivers of therapeutic consumption identified by Lears (1983) remain relevant to contemporary socio-cultural dilemmas. Although the therapeutic quality is not necessarily the theoretical core of these servicescape studies, analysis nevertheless reveals 
their compensatory function in sustaining the status quo through commercially mediated therapeutic performances. We discuss the socio-cultural dilemmas in turn but recognize that servicescapes are not mutually exclusive to one dilemma.

First, servicescapes can offer a source of re-energization to compensate for the alienation inherent in post-industrial, corporate capitalism (Belk and Costa 1998; Canniford and Shankar 2013; Celsi et al. 1993; Goulding et al. 2009; Scott et al. 2016). In providing a platform for pleasure, play and physicality, these servicescapes offer a cathartic quality that resolves workplace tensions and affords a more fulfilling work-life balance. However, these regenerative and restorative escapes remain temporary alternatives to corporate life and, in this sense, they are "hidden" and "clandestine" acts of subversion (Scott et al. 2016, 19) that do little to disrupt the dominant social system. Indeed, their containment ultimately reaffirms the mundanity of corporate life (Goulding et al. 2009).

Second, various studies reveal that consumers are drawn to servicescapes that offer relief from urban malaise through interaction with the natural environment (Arnould and Price 1993; Arnould et al. 1998; Belk and Costa 1998; Canniford and Shankar 2013). For example, Arnould et al. $(1998,415)$ discuss the healing power of the wilderness servicescape propelled by a narrative of restoration that reaches "below the surface of culture and civilization." These servicespaces offer a sense of renewal that enable consumers to return to urban life refreshed and rejuvenated.

Third, servicescapes can offer spiritual revitalization in the face of a consumer culture where conventional religious institutions no longer hold unquestioned authority and prominence (Crockett and Davis 2016; O’Guinn and Belk 1989; Sherry and Kozinets 2007). Such servicescapes manage tensions between religious ideology and consumerism (Crockett and Davis 2016) and are embraced by consumers who face judgement and ridicule for their religious beliefs (O’Guinn and Belk 1989), or who are frustrated with traditional religious 
institutions (Sherry and Kozinets 2007). Another pertinent example of spiritual revitalization is found in Moisio and Beruchashvili's (2010) investigation of support groups when they propose a spiritual-therapeutic model of consumer well-being. Such servicescapes encompass empathetic support from like-minded others that would otherwise be absent from existing social networks.

These studies suggest that servicescapes can orchestrate intense consumer emotion. Some servicescapes orchestrate the ritualized performance of festive emotions, such as pleasure and happiness (Belk and Costa 1998; Goulding et al. 2009; Guinn and Belk 1989). However, the profiling of emotional suffering remains rare, with prior servicescape work geared more towards settings that facilitate emotional distance from everyday worries and tensions (Arnould and Price 1993; Belk and Costa 1998; Canniford and Shankar 2013; Celsi et al. 1993; Goulding et al. 2009; O’Guinn and Belk 1989; Scott et al. 2016). Some of these consumption settings involve fear and anxiety that are orchestrated as enriching through a sense of personal achievement (Arnould and Price 1993; Canniford and Shankar 2013; Celsi et al. 1993; Tumbat and Belk 2011). Although these servicescapes enable emotional suffering, servicescapes where emotional suffering is central to performance rituals have been neglected. We address this oversight because the privileging of emotional suffering is particularly therapeutic (Illouz 2007) and compensates for the emotion deficit that is characteristic of Western consumer culture (Furedi 2004). To enable our theorizing of the therapeutic servicescape, we turn to work in emotional geographies which offers a useful framework for understanding the emplaced, socio-spatial articulation of emotion.

Theorizing Emplaced Consumer Emotion 
From an emotional geography perspective, emotion is not an interiorized subjective mental state but emerges through socio-spatial interaction (Davidson et al. 2012). Davidson and Milligan's $(2004,524)$ discussion of an "emotio-spatial hermeneutic" highlights the circular nature of the link between people and places: "emotions are understandable'sensible' — only in the context of particular places. Likewise, place must be felt to make sense." From this perspective, emotion should be approached as a "relational, connective medium" (Bondi 2005, 433) or "a form of connective tissue" (Davidson and Milligan 2004, $524)$ that situates the individual within social geographies of place. Consequently, emotions are characterized by a dynamism that means they are more readily emplaced in some settings than others.

We draw on emotional geography literature to build knowledge of how emotions are localized to therapeutic socio-spatial settings. Prior consumer research shows that emplaced, market-mediated consumer performances can be emotionally charged (Arnould and Price 1993, Celsi et al. 1993, Goulding et al. 2009, Scott et al. 2016). However, the way in which these consumer performances are tied to emotional geographies has not been fully addressed. Enabled by the concepts of therapeutic landscapes and emotion scripts, we explain how consumer emotions are geographically and socially situated in order to more fully appreciate the therapeutic elements in prior studies.

Therapeutic landscapes are useful in highlighting the restorative outcomes stemming from self-landscape interaction (Gesler 2003). Therapeutic landscapes were originally understood as "landscapes associated with treatment or healing" (Gesler 1992, 735-36) but later extended to encompass landscapes that promote well-being (Williams 2002). This extension of meaning suggests that people can be attracted to therapeutic landscapes to seek resolution or ease of problems. Therapeutic landscapes integrate a person's physical, mental, spiritual, emotional, and social states, with four types of environment - natural, built, 
symbolic, and social (Gesler 2003). We follow Conradson's (2005) conceptualization to acknowledge that landscapes do not have intrinsically therapeutic properties. Therapeutic outcomes do not arise simply by being in a particular place but require active consumer participation. Conradson's (2005) perspective is helpful because it draws attention to how therapeutic landscapes can rework broader socio-cultural dilemmas encountered in other landscapes. Prior research on therapeutic landscapes does not tend to focus on commercial settings, however, we find the therapeutic landscapes literature is helpful in theorizing how market-mediated emotions are socially and geographically cultivated.

Emotion scripts align with dramaturgical theories of emotion that dictate what emotions should be experienced and expressed in social contexts (Turner and Stets 2006). A sociocultural perspective on consumer emotion can generate new insights for consumer cultural studies (Gopaldas 2014), yet scholars have been slow to take up this opportunity. Emotion scripts are discussed by Fredman $(2004,14)$ in terms of "local emotion grammars," reinforcing the emplaced nature of emotion. Various theorizations have elaborated on the different types of emotion scripts, particularly, Hochschild's (1983) feeling rules which refer to private emotion systems that guide the appropriate duration and intensity of feelings in social contexts. Within westernized culture, happiness and contentment are embraced in contrast to other emotional states which may be regarded with suspicion (Furedi 2004). "Rule reminders" from others often serve to highlight emotional deviations (Hochschild 1983, 58). Since deviation from emotion scripts can lead to negative emotions (Turner and Stets 2006), consumers' emotional displays are often self-conscious and deliberately driven by perceived judgement from others (Hung and Mukhopadhyay 2012). As a result, consumers may suppress their emotions from fear of being judged as "foolish" or "inauthentic" (Gopaldas $2014,1007)$. In such situations, consumers engage in emotion-work strategies to resolve the conflict between feeling rules and their actual emotional states (Hochschild 1983; Turner and 
Stets 2006). For example, Tumbat and Belk (2013) highlight the suppression of emotions such as fear, anxiety, and homesickness as an important performative competency enacted by climbers. Hochschild (1983) suggests that feeling rules vary across social groups. From a gendered perspective, feeling rules for men may dictate greater restraints in terms of expressing emotions (Fredman 2004; Hochschild 1983). Indeed, men increasingly turn to compensatory consumption practices in response to anxieties surrounding threatened masculine identities (Holt and Thompson 2004) and any nonconventional performances of masculinity can create stigmatization and the questioning of cultural legitimacy (CoskunerBalli and Thompson 2013). For example, Belk and Costa (1998) outline that masculine identity embraces hedonistic emotions yet suppresses tears.

The suppression of tears aligns with a "verbal overshadowing" (Illouz 2008, 245) that prioritizes linguistic disclosure over nonverbal therapeutic release. Various studies have revealed nonverbal aspects of therapeutic consumption, such as the bio-social pleasures of clubbers (Goulding et al. 2009), the phatic communion amongst surfers and skydivers (Canniford and Shankar 2013; Celsi et al. 1993), the sensory communion with nature (Arnould and Price 1993; Canniford and Shankar 2013), and the ritualized performance of pain (Scott et al. 2016). However, in these studies nonverbal therapeutic release is associated with escapism from emotional suffering. In contrast, research on the confrontation of emotional suffering through therapeutic communities prioritizes the verbal, and reveals that the sharing of emotional stories within both face-to-face and web-based support groups is a conduit towards improved well-being (Moisio and Beruchashvili 2010; Tian et al. 2014). Communicating emotional stories can help to generate change, solve problems, and cope with adversity (Frank 2013; Illouz 2003; Wong and King 2007). However, issues of emotional suffering cannot be fully captured or represented through spoken language. As Harrison $(2007,593)$ explains, "pain, loss, and affliction tend toward the erosion and depletion of the 
capacity for speech and communication, toward the unravelling of our words and sentences into stutters and inchoate cries.” As yet, crying has not been considered within prior theorizations of market-mediated performances.

Crying can manifest for many different reasons, ranging from physiological tears (e.g. reaction to allergies) to manipulative tears (e.g. getting one's own way) to emotional tears, which express particular moods evoked by significant life experiences (Vingerhoets 2013). Crying is associated with nourishment, sustenance, vitality, and renewal (Lutz 1999) and has valuable adaptive and reflective functions by providing "time out" to enable confrontation of suffering (Bonanno, Goorin, and Coifman 2008). As Kottler (1996, 17) suggests, crying represents "those times when you are most moved, when you are most alive, in the sense that your head and your heart, your very spirit, are all synchronized in a single effort to communicate what is going on inside you." Crying can only be fully understood if considered within the broader socio-spatial context in which it occurs (Vingerhoets 2013). We suggest that servicescapes that orchestrate ritualized crying can be therapeutic. The conceptual tools of therapeutic landscapes and emotion scripts enable us to place the socio-spatial cultivation of emotion at the center of our analysis. In doing so, we provide a detailed discussion of the emotional geographies of the therapeutic servicescape.

\section{RESEARCH METHODS}

Context: Lourdes Pilgrimage

Our context to theorize therapeutic servicescapes is the religious pilgrimage site of Lourdes. Pilgrimage centers on the movement between two distinct poles - "Familiar" and “Other" (Morinis 1992). The former refers to the known, human, imperfect, and mundane 
world, and the latter to the mysterious, divine, ideal, and miraculous world. This movement enables pilgrims to resolve the oppositions between the "imperfection" of their lived experience and the "ideal" that they seek (Morinis 1992, 26). Traditional understandings of pilgrimage align with the idea of the "journey of the suffering body" (seeking miraculous cures to physical illness), whilst more recent understandings of pilgrimage privilege "the journey of the suffering soul" (seeking relief from emotional suffering) (Eade 2013, xvii).

Located in the French Pyrenees and inhabited by only 16,000 people, Lourdes is annually sub-populated by approximately six million pilgrims. The narrative of Lourdes stems from a series of apparitions in 1858 between fourteen-year-old Bernadette Soubirous and a woman, who was authenticated by the Catholic Church in 1862 as Our Lady, the Mother of Jesus Christ. Lourdes is the third largest Catholic pilgrimage site in the world, and boasts one of the largest religious landscapes. This religious landscape encompasses 52 hectares of churches, basilicas and spiritual centers.

Religious and marketplace structures have been subject to Durkheim's dichotomy, with the former relating to the sacred and the latter to profane (Belk, Wallendorf, and Sherry 1989). Pilgrimage thus is traditionally believed to possess a sacred authenticity, which should be unspoiled by consumerism (Conradson 2007; Crockett and Davis 2016; Husemann et al. 2016). However, Reader $(2014,14)$ believes the dichotomy between pilgrimage and marketplace is fallacy. This is evident in O'Guinn and Belk's (1989) work on Heritage Village where religious centers of worship coexist with the shopping mall. Similarly, Lourdes offers consumers a bustling consumptionscape including 208 hotels, over 100 restaurants, 220 souvenir shops, and numerous tourist organizations offering trips around the Pyrenees (Fargues 2011).

We are by no means pioneers in the contextual area of Lourdes, with the site investigated across disciplines, for example, anthropology (Turner and Turner 1978), 
geography (Gesler 1992, 2003), theology (Lauretin 1994), and tourism (Eade 1992). Lourdes' alignment with the Mother of Jesus Christ has led to it being perceived as feminine and nurturing, and often described as the "emotional side of Catholicism" (Dahlberg 2013, 35). However, scholars have often overlooked emotions in Lourdes. For example, Dahlberg (2013) emphasizes the suffering body, failing to acknowledge emotional suffering at Lourdes. Turner and Turner (1978) prioritize the structure and social anti-structure dichotomy over emotion. Gesler's $(1992,2003)$ exploration of the therapeutic landscape of Lourdes is the most closely aligned with this study, but our work is distinct in three key ways. First, Gesler $(1992,2003)$ predominantly focuses on therapeutic environmental properties whilst we extend this perspective by exploring how emotions are collectively reproduced through therapeutic consumer rituals. Second, he neglects how the therapeutic landscape of Lourdes relates to a "broader web" (Conradson 2005, 338) whereas we examine the broader sociospatial contexts in which the therapeutic servicescape exists. Third, prior work on therapeutic landscapes overlooks nonverbal activities and practices (McCormack 2003). Our discussion of therapeutic ritual embodiment acknowledges the extra-discursive performances of emotional suffering orchestrated by therapeutic servicescapes.

Data Collection

This ethnographic study was carried out over a three-year period by the first author. In keeping with standard ethnographic practice a "diversified toolkit" (Sherry 1998, 4) of methods were employed. Figure 1 offers an illustrative timeline of the research journey drawing on the hermeneutic spiral (Gummesson 1991; Thompson, Pollio, and Locander 1994) and the hermeneutical access stages offered by Stenbacka $(2001,554)$. 
Insert figure 1 about here

As a practicing Catholic, the first author possessed the pre-understanding and tacit knowledge of religious terms and rituals (McAlexander et al. 2014). Pre-understanding enabled socio-historic knowledge of the context and links to useful "gatekeepers" (McCracken 1988), for example, a Lourdes historian, and a local priest who permitted initial access to the research site. An initial scoping fieldtrip was undertaken that enabled access to the organization and access to core teams through networking with key gatekeepers such as Head of English chaplaincy, representatives from voluntary associations, shop vendors, etc. These network links were strengthened during further fieldwork at Lourdes, becoming the catalyst for access to informants. Fieldwork was based on participant observation (Brewer 2000), which incorporated volunteering with pilgrimage groups. The three week field trip in 2011 was conducted through a French on-site volunteering association and involved answering pilgrims' questions and providing directions around the Sanctuary. The researcher spoke to 774 people with some conversations lasting only a few minutes and others continuing up to 90 minutes.

Fieldwork was also undertaken with a Scottish pilgrimage group in July 2012 which involved supporting sick pilgrims. This was particularly useful as the researcher travelled with the group and was involved in all their activities throughout the week-long pilgrimage. Other field work was organized independently during which the researcher spent time within the Sanctuary and the surrounding town. These trips were scheduled to coincide with key religious festivals and peak times at Lourdes. At all times the researcher was overt regarding her role and informed consent was provided by all respondents included in field-notes and visuals. Fieldwork resulted in over 200 pages of double spaced field-notes, approximately 3000 visuals, and many informal, serendipitous interviews with pilgrims. When permission 
was granted these serendipitous discussions were audio-recorded, transcribed verbatim, and included within field-notes.

To enable access to person, depth interviews were conducted with twenty-three respondents lasting from thirty minutes to four hours. As a means of tracing the pilgrimage journey more fully, some respondents were interviewed multiple times. The sample included males and females and ranged in age from 17 to 93 . Some respondents were first time pilgrims to Lourdes whilst others were recurrent. Twenty-one of the respondents were Catholics, one was Christian from the Episcopalian denomination, and one viewed herself as spiritual (table 1 outlines respondent details). All interviews were transcribed verbatim, tallying over 1000 double spaced pages of transcription. Pseudonyms are used to protect respondent identities. Interview content centered on understanding the therapeutic aspect of Lourdes. During interviews the emerging theme of emotional suffering became apparent, prompting more detailed probing throughout the remaining phases of research and analysis.

Insert table 1 about here

Data Analysis

As illustrated by figure 1, analysis was approached utilizing a hermeneutic and iterative logic (Stenbacka 2001; Thompson 1997), with data analyzed through the movement back and forth between the context, data (emic), and theory (etic), enabling holistic access to phenomenon. Interpretation was validated during a final week-long reflective fieldtrip to Lourdes and through member checks with key respondents (Wallendorf and Belk 1989). Much like the varied background of McAlexander et al.'s $(2014,863)$ research team, the second author as a non-Catholic "enriched the overall dialogue and the co-constitution of 
interpretation.” Both authors regularly met throughout the study, including between each field-trip, to discuss data collected, emerging themes, and potential theoretical positioning.

\section{FINDINGS}

The substantive contribution of this article is the development of the concept of the therapeutic servicescape through the theorization of emplaced, market-mediated performances of emotional suffering. We illustrate that emotion is emplaced within the sociospatial features of therapeutic servicescapes. The three servicescape features are evocative spaces, ideological homogeneity, and restorative emotion scripts. These features catalyze three therapeutic consumer rituals. Just as psychotherapy is composed of (1) relating intimately with a trusted healing agent and social group, (2) releasing emotional suffering, and (3) generating positive emotional reserves (Frank and Frank 1993), so too consumer rituals within therapeutic servicescapes are composed of therapeutic relations, therapeutic release, and therapeutic renewal. Figure 2 serves as the framework for the presentation of our findings.

Insert figure 2 about here

Therapeutic Servicescape Features

Similar to Gesler's (2003) conceptualization of therapeutic landscapes and Sherry's (1998) conceptualization of servicescapes, we demonstrate that a therapeutic servicescape comprises multiple socio-spatial features: evocative spaces, ideological homogeneity and restorative emotion scripts. These features reveal that emotions are geographically and 
socially orchestrated. We discuss these features separately but it is the holistic interaction between them that constitute the therapeutic servicescape.

Evocative Spaces. Evocative spaces in Lourdes encompass natural, built, and symbolic environments and are defined by their capacity to bring powerful archetypes, memories, visions, and their attendant feelings to mind. The pilgrimage site comprises churches, basilicas, and spiritual centers (see figure 3) which coalescence upon the narrative of Lourdes. Religion is the most important aspect of culture in terms of the cultivation of emotion, particularly through the use of symbols (Campbell 2005). Lourdes is founded on five symbols: 1) the rock, 2) the water, 3) the light, 4) the crowds, and 5) the sick. Table 2 provides further detail on how these symbols fit with the overarching narrative of Lourdes. The examples of therapeutic rituals reveal that the narrative of the apparitions continues to inform contemporary Lourdes pilgrimage. These rituals are discussed at appropriate points throughout the remainder of the findings.

\begin{tabular}{c}
$\begin{array}{c}\text { Insert table } 2 \text { and figure } 3 \\
\text { about here }\end{array}$ \\
\hline
\end{tabular}

Together, these symbols add a thematic coherence to the servicescape as each is rooted in the apparitions of 1858. Theming in the Lourdes servicescape is consistent with Bryman's (2004) discussion of Disneyization as the strong Lourdes narrative distinguishes it from a place that would otherwise be homogeneous and unremarkable. Pilgrims certainly view Lourdes as unique and field-notes are littered with the French "particulière," which translates to special or distinctive, and illustrates the localized significance of the pilgrimage site. Theming provides the servicescape with meaning that transcends the natural and built environments (Bryman 2004). James alludes to this evocative quality of Lourdes: 
"The place is unique and last year I was asked to make a short presentation to the youth group and I said to them it was indefinable, untouchable, unquantifiable, you cannot really express in words what Lourdes is about, it is just a sense you get... Unless you go and see, touch, feel, and experience, you cannot relate to it" (James).

James captures the affective power of Lourdes, drawing attention to its sensory qualities that cannot be verbally communicated. For Thrift $(2008,222)$, the transmission of affect is a function of space to the point that "space and affect are often coincident." Affect precedes cognition, is a precursor to emotion, and manifests on a somatic register through atmospheres (McCormack 2003; Thrift 2008). The relational flow between the spatial features of Lourdes and visiting pilgrims engenders a distinctive emotional emplacement. Hill, Canniford, and Mol $(2014,388)$ suggest that atmospheres can "take hold" of consumers' bodies and, throughout our findings, we reveal that the symbolism of Lourdes creates an atmosphere that orchestrates emotional and embodied responses that compensate for emotional restrictions.

Drawing on Illouz $(2003,152)$, we suggest that the Lourdes narrative has created an "industry of healing" that constitutes "an ongoing source of capital." The annual running of the Sanctuary is financed through the donations of pilgrims. It is part of the standard script to leave donations when partaking in the therapeutic rituals, for example, donations are left for candles, visiting the Baths and during religious services. Yasmina, our only non-Christian respondent, referred to this aspect of Lourdes as a "money-making machine." Whilst Yasmina points to the commodification of emotion, other respondents' receptiveness to the Lourdes narrative means that they welcome monetary sacrifice as a means of communicating with the sacred (Belk et al. 1989). The "industry of healing" at Lourdes extends to the marketplace where 220 souvenir shops offer pious and kitsch products, ranging from the holy 
rosary bead (a Catholic prayer tool) to luminous, sparkling religious memorabilia. Thus, the Sanctuary has transformed the local economy from a derelict, rural town to the second largest tourist destination in France (Fargues 2011).

Ideological Homogeneity. Ideological homogeneity refers to the like-minded beliefs that provides a sense of safety and security through the convention of tolerance and acceptance of the behaviors, emotions, and beliefs of others. Kelly outlines the rarity of this ideological homogeneity:

"I found that quite moving, the fact that there were so many people from all different places coming with a common purpose. I think the first time I realized the scale of that would have been the torchlight procession. I just thought that was really, really powerful and it makes you feel safe because there's nowhere else like Lourdes where you know that everybody is there for the same reason. That was the one thing that really struck me the first time I went" (Kelly).

The procession discussed by Kelly is an evening candlelit procession that involves pilgrims walking, singing, and praying together around the Sanctuary. Often attracting up to several thousand participants, each of whom carry a candle, this ritual is one of greatest expressions of the symbol of light at Lourdes (Fargues 2011). Sharing in this ritual with such a large number of other pilgrims facilitates a sense of ontological security. Ontological security is anchored in constitutive rules (Phipps and Ozanne 2017), and, in Lourdes, pilgrims reinforce Catholicism as a common frame of reference through their performance of religious rituals. Similar to support groups (Mosio and Beruchashvili 2014), participation in the procession enables Kelly to encounter a social network of like-minded individuals which projects a sense 
of safety. Many respondents express appreciation that the ideological homogeneity of Lourdes is such that they do not have to explain or justify their faith. This acceptance runs counter to respondents' experiences in their home environments where practicing Catholicism results in them being socially labelled and ridiculed:

"We can talk about everything under the sun-you are on the bus and you are hearing people talk about very inappropriate things to do with their sex life or whatever-but when it comes to the things of God and spiritual life we just clam up. It is as if we don't have the vocabulary to talk about it and then you go to Lourdes, and there is acceptability about it. We may not be able to articulate it very well but there is a feeling of wanting to, and a sense that it is okay to talk about these kinds of religious experiences we have, that we would never mention here in Scotland, but you do in Lourdes. We are particularly bad for it because in the UK we are far too sophisticated to talk about God and the spiritual experiences we have. You can imagine the faces, they would just look and go "you are a weirdo, you know, the Crazy Catholic, I think we will just pigeon hole her right there because she is a psycho.” The Crazy Catholic thing" (Anne).

Anne's comments highlight the stark contrast in the social features of Lourdes and respondents' home environments in Scotland. Anne highlights that topics once deemed taboo for public discussion, such as sexual relationships, have become normative conversations within her home environment. Conversely, religious conversation and expression have been silenced within the public domain, which is significant for our respondents given its centrality to their sense of self. Vernacular terms such as Crazy Catholic refer to extremely devout Christians who evangelically attempt to spread their faith and is used disdainfully to mock 
staunch religiosity. Fear of this judgement means respondents feel silenced in the open practice and discussion of their religion, resulting in their religious identity being "backgrounded" (Weinberger 2015) in their home lives. For example, Lisa feels repressed to openly practice her faith, even in those places of supposed religious homogeneity such as Catholic school: "I feel like I'm allowed to be a Catholic in Lourdes. I went to a Catholic school, and even in Catholic school, I would get picked on for going to Mass [religious service]." At the time of the interviews, the silencing of religious conversations in the respondents' home environments was heightened due to significant media coverage on the resignation of the Cardinal, leader of the Catholic Church in Scotland, following allegations of inappropriate sexual conduct towards junior and student priests. The localized nature of the scandal further undermined the credibility of the Catholic Church which was already tarnished following years of international exposure concerning sexual abuse. However, despite these undesirable cultural conditions, respondents do not abandon their Catholic identity. Although many respondents acknowledge "struggling" with their faith within this context, much like Arsel and Thompson's (2011) strategy of symbolic demarcation, they distinguish their own beliefs from institutional "shortcomings." For example, Danielle comments, "I have my faith and that is nothing to do with how corrupt the church is, it has to do with what I believe and what I am." This strategy insulates and distances respondents from the broader undesirable cultural meanings.

In Lourdes, where symbols of Catholicism dominate and there is greater homogeneity in religious beliefs, religious conversations are legitimized. This alternative social context reinforces the sense of safety associated with Lourdes. The legitimization of religious conversations, however, often raises complex and challenging issues and can reveal alternatives in the interpretation of religious dogma. For example, during the July 2012 fieldtrip, a homosexual couple travelled with the 
pilgrimage group. Some viewed the couple's relationship as "against the church," whilst for others it was "beautiful," "a sign of the times," and "progressive" (fieldnotes). Our findings suggest that these alternative interpretations are not problematic but rather, respondents welcome the opportunity to discuss and debate their beliefs within a safe environment. Drawing on Canniford and Shankar (2013, 1065), pilgrims employ a strategy of "ideological masking" to silence the betrayals and contradictions that risk undermining the narrative of ideological homogeneity.

Restorative Emotion Scripts. Restorative emotion scripts enable emotional release that promotes well-being. The majority of respondents live in Scotland where the social order is "undemonstrative," requiring a "stiff upper lip." Respondents regard their home environments as being "emotionally straightjacketed," you "don't show emotion," especially not in public and, for some, not even in private. James shares that “typically, where I'm from people are very introverted and don't like to show their emotions but Lourdes brings it out and that is really quite profound." These comments are reminiscent of Craig's (2004) assessment of the dominance of logic over emotion within the Scottish culture and a national character that is fearful of drawing attention to oneself. The performance of sentiments (Gopaldas 2014) is largely absent within respondents' home towns. This is why the Lourdes therapeutic servicescape is viewed as a "profound" opportunity to release emotional suffering:

"A lot of times in normal life if you're upset you don't talk about it. In Lourdes it's ok just to cry your heart out, and that's ok, people get that and don't judge you, and just are there to support you and give you a hug ... Everybody just hugs each other, has a wee [little] cry on their shoulder, that's it. And then once everybody's done 
that, that's ok, nobody judges it and then everybody goes back to the pub and has a drink. So it's a totally safe space to do it and nobody will think "oh for God's sake" or try to make you happy" (Miriam).

The social support provided by other pilgrims coupled with the legitimization of emotional outpourings suggest that the feeling rules regarding emotional displays in Lourdes are contrary to those in respondents' home environments. Feeling rules can be identified through the reactions of other people (Hochschild 1983) and, as noted by Miriam, emotional displays at home are often approached as a problem that needs to be solved as others "try to make you happy." These "rule reminders" (Hochschild 1983, 58) are absent in Lourdes and instead, responses to emotional outpourings elicit comfort, as other people do not try to stop emotional display but instead simply provide a shoulder to cry on. Matthew recalls being on the receiving end of his friend's emotional unburdening:

"I was in one of the cafes with my friend, we were chatting normally and then she went really quiet. I asked "You alright?" and she replied "no, I'm not," and she was crying her heart out and she was telling me everything she was going through. I put my hand around her and she was just like "I've never told anyone any of this, I've never felt like this before." So, I think Lourdes in general is good for us, inasmuch as I think a lot of the time you don't have an opportunity when you're at home to lay all your feelings out and it's almost like it's a safe breakdown, a safe space to do that" (Matthew). 
Many shared Matthew's sentiment that Lourdes is a "safe place" to breakdown, with Lisa explaining “in Lourdes I'm safe, emotionally safe and I don't feel like that back home". The repetition of the word "safe" by several of our respondents points to the cathartic nature of restorative emotion scripts. The social support and lack of judgment, coupled with the evocative spaces discussed earlier, provide a platform that is conducive to the "performance of suffering selves" (Illouz 2003, 80). Matthew's example highlights that these emotion scripts extend beyond the Sanctuary and are equally applicable in the marketplace. Lourdes becomes a place where emotion scripts encourage the expression and exposure of trauma and its associated emotions. Similar to previous work, seemingly negative emotional states are orchestrated in ways that produce enriching emotional outcomes (Arnould and Price 1993). As Matthew points out, therapeutic servicescapes are "good for us" and can facilitate wellbeing. From this perspective, the expression of suffering is seen as virtuous and leads to personal growth and self-development (Illouz 2003).

Further, the Lourdes emotion scripts associated with masculinity are particularly restorative. Garry volunteers with a pilgrimage trust taking disabled, sick, and disadvantaged children to Lourdes, which often leads to intense emotions:

"When I was in the youth group with [pilgrimage trust group], they always do a kind of ceremony on the last night and there isn't a single person who doesn't cry at it. I mean, I think it's because people are emotional about leaving the kids, people are emotional because it's getting to the end of the week, and they know they aren't going to see people for months at a time. Other folk are just reflecting on everything, and you cry and it's totally okay. And you'll get guys who are right tough, hard guys, who would never dream of crying, and then they are standing there bubbling, like 
blubbering away, and you're standing there with your arm round them. It's not like you will stand in the pub later and be "oh, you were crying, haha”, it's just totally you put your arm around them, then it's done" (Garry).

Many of our male respondents are of the perspective that the outpouring of emotion within daily life is a "sign of weakness" which contravenes feeling rules and may lead to social ridicule. In Lourdes, as noted by Garry, emotions are released without fear of judgement. Removal from their home environment allows male respondents to challenge habituated gender dispositions (Thompson and Ustuner 2015), transcending the crisis of masculinity they may otherwise experience (Holt and Thompson 2004).

The focus thus far has been on the features of the therapeutic servicescapeevocative spaces, ideological homogeneity and restorative emotion scripts. These features are not inherently therapeutic but are reproduced through the performance of three therapeutic consumer rituals.

\section{Therapeutic Consumer Rituals}

Therapeutic consumer rituals are scripted performances that are orchestrated by the socio-spatial servicescape features. The three consumer rituals evident within the therapeutic servicescape are therapeutic relations, therapeutic release, and therapeutic renewal. We discuss each of these rituals in turn, but recognize that they are interrelated as depicted in figure 2. Table 3 encompasses examples from our data demonstrating the consumer rituals beyond those discussed in the text below. Whilst other scholars of Lourdes have dismissed the commerciality of the town as separate and even detrimental to the therapeutic and 
religious Sanctuary (Eade 1992; Gesler 2003), we reveal that the commercial marketplace is as much a part of therapeutic servicescape as the religious Sanctuary.

Insert table 3 about here

Therapeutic Relations. Therapeutic relations are defined as relating intimately with trusted fellow consumers. As noted previously, respondents face various social conditions within their home towns which compels them to silence their Catholic identity. These social conditions undermine relationships, recall, for example, Anne's comments surrounding perceptions of "Crazy Catholics". The therapeutic servicescape plays an important role in compensating for these social deficits. Respondents shared that the experience would not have been "as moving," "as wonderful," "as supportive," or "as fun" without the sense of camaraderie afforded by therapeutic relations. Danielle recalls the unknowns of her first trip to Lourdes:

"I did not know what to expect from the group but it was very central to having a good time and getting the most out of it. I did not realize just how much I would get from it. You know just sort of being open to these new friendships and these new connections. It was a very, very welcoming atmosphere, they are all there to do the same work and to have a good time, so it is a very positive group where people are welcome. I knew I was going to work and help other people but I didn't realize that people would help me. They helped me with my confidence, my happiness, reassured me of my faith. I did not realize it would be quite as powerful” (Danielle). 
Danielle's "new friendships" and "new connections" are "powerful” in developing therapeutic relations. Danielle travelled to Lourdes to care for sick pilgrims but benefits herself through newfound confidence, happiness, and reassurance in her faith. Her words demonstrate the reciprocity evident in these relationships. Although Danielle's confidence issues are very different to the physical disabilities experienced by those she is caring for, the indiscriminate nature of suffering as a "general narrative of identity" means that the distance between sufferer and non-sufferer is minimized (Illouz 2003, 102). This highlights the interchangeable roles within the healing relationship as pilgrims like Danielle fluctuate between sufferer and healing agent (Frank and Frank 1993). In this sense, Lourdes can be regarded as what Illouz (2003) would term a therapeutic spectacle as pilgrims do not hide from other peoples' suffering, but seek out these vicarious experiences in the process of constituting their own well-being.

Such reciprocity highlights the significance of others to the ritualized performances of emotional suffering. Sometimes this takes the form of embodied support, for example, recall the earlier comments from Miriam and Garry indicating that the restorative emotion scripts at Lourdes involve embodied support through hugging. This support extends to strangers with examples provided by Christine and Veronica (table 3) about the physical support offered to others whilst volunteering. This embodied support is similar to Illouz's (2003) discussion of the ethic of care. This form of support reinforces how tender and nonsexual aspects of touch can come to the fore when removed from standard social conventions (Goulding et al. 2009).

Another manifestation of this ethic of care is found through respondents' compassion for others which often moves them to tears. These sentimental tears act as reminders of the significance of the suffering to which others are exposed (Vingerhoets 2013). Sentimental tears are particularly discussed in relation to the therapeutic ritual of The Anointing of the Sick, a religious service when sick pilgrims receive a blessing as a means of promoting 
emotional and physical healing. As Matthew describes “it's a very emotional mass for them [the sick] and you can see it, it's palpable. There's hardly a dry eye in the place, you are often sobbing." Although Matthew is not sick himself, the service is emotionally heightened because of his empathy for others. He recalls such empathy upon witnessing the reaction of a sick pilgrim explaining her emotion as being "so strong, you could feel it." Matthew's words draw attention to the "kinetic empathy" (Thrift 2008, 237) that flows between pilgrims. Thrift (2008) explains that this form of empathy is driven by an affective contagion that highlights the porous nature of the self-other divide and individuals' automatic, and subconscious tendency to imitate others. Many respondents describe this service as a "greet [cry]-fest," and Anne suggests, "being overly emotional, being in company feeds that, there is nothing like four of you or more together having a good greet [cry] at something”. Moisio and Beruchashvili $(2010,863)$ reveal how emotional storytelling in support groups can be comforting and cathartic and induce "a collective "coming out"" through the reciprocal sharing of experiences. Our research uncovers a similar sense of contagion but the focus is on collective tears rather than collective talk. The shared experiences of tears are powerful signs of intimacy that connect people at a "primal level" (Kottler 1996, 21). The therapeutic servicescape thus reinforces the relational nature of emotion with collective tears cementing therapeutic relations and strengthening social bonds.

The ethic of care at Lourdes is not bound to the Sanctuary but extends to informal socializing. As illustrated by Brendan (see table 3), the marketplace affords pilgrims the opportunity for "genuine time with each other." Anne explains further:

“It can be very frustrating at home, you've got things to attend to, somebody comes to the door and they just need a wee chat and you feel like you cannot give them much time. That is a tension in me, it just frustrates me. Whereas in Lourdes I find 
those special moments... Especially in the cafes and restaurants, you get a lot of those special moments when you can actually just sit down with Jean or whoever and say okay what is happening? And there is a lot of banter but then you cut through some of the banter and you get to the heart of why their son is no longer talking to them and why they are estranged from their families, how they are afraid that this ulcer is going to kill them, whatever it is, and that is a privileged moment" (Anne).

Therapeutic relations at Lourdes compensate for the social suffering that respondents may otherwise experience. For Illouz $(2003,13)$, the demands of modernity are linked with a failed sense of self and "real social suffering" in the form of loneliness, stress, and the domination of individualization. Evidence of the fragility of interpersonal relationships is found in Anne's comments about the difficulty of finding time for friendship and Matthew's discussion (see table 3) of the sick pilgrim who had no family. Questions of suffering are not adequately addressed within contemporary consumer culture (Illouz 2003). This reinforces the significance of the therapeutic servicescape where social support facilitates performances of emotional suffering.

Therapeutic Release. Therapeutic release refers to the exposure of emotional suffering. Unlike other religious-themed servicescapes where emotional displays are rare (Crockett and Davis 2016), the dramaturgic structure of Lourdes rituals orchestrates an emotional reaction. Confession is a Christian ritual which involves disclosing transgressions to a priest and receiving absolution from sin and guilt. Drawing on his experiences as a priest, Brendan suggests that confession at Lourdes can be an emotionally healing ritual: "We get bruises as we go through life, we have our dents, we have our hurts, we have our emotional bruises, and all of those things. And I think people come to Lourdes and we become more 
aware of that, and it is in confession this happens. Confession, it's a run of the mill experience at home, but here [at Lourdes] there can be something very special about it... It's a kind of healing process." Emotional unburdening through confession can be explained through its socio-spatial features. First, confessions at Lourdes are distinguished from other "run of the mill" confessions because they move from "formally scripted and unvarying" dialogue to a "casual" (Rook 1985, 253) script. Second, catholic confession tends to be heard via a closed curtain or grate within a confessional box which has separate sections for the priest and the confessor. In contrast, the Lourdes confessional setting has a different material configuration:

"I entered confession and was astonished that there was no separation between myself and the priest, rather the confessional was like a simple meeting room. There was a small circular table and two chairs. On the table lay a crucifix, the priest's prayer book and a box of tissues. At home you list your sins, pray with the priest, and receive absolution, it's all over in around ten minutes. However, today I was somewhat taken aback when the priest spent close to an hour chatting to me. I found myself telling him about my grief. I got so upset. I kept apologizing but the priest said to me "it's okay, we all need a good cry from time to time and you'll feel better for it". I do feel better. I never realized it but I must have been bottling up my grief and now I've shared it I feel a thousand times better" (field-note from June/ July 2011).

Moisio and Beruchashvili (2010) reveal that social features are central in facilitating emotional unburdening during confession. We find both social and spatial features orchestrate this therapeutic ritual. As noted earlier, emotion scripts that are accepting of 
displays of distress point to the idea of a "safe breakdown." The spatial layout of the confessional reinforces this perspective, and although the materiality is rather mundane, it is nonetheless significant to the therapeutic release. The lack of partition creates a setting conducive to unrushed conversation, while the addition of a box of tissues signals that crying is acceptable. Indeed, we suggest that these features of the confession actively engineer emotion. This is where the therapeutic potential comes to the fore and the field-note demonstrates that such emotional release is cathartic and brings welcome emotion shifts. The field note also reveals that these ritualized performances can uncover parts of the self that are otherwise unacknowledged. Other therapeutic rituals have a similar emotional outcome, table 3, for example, includes accounts of suppressed grief and fear of illness relapse. These examples relate to experiences and feelings that consumers do not usually vocalize. Within such contexts, tears are as central to therapeutic release as spoken language.

The Grotto is another key setting for therapeutic release and is regarded as "awe-inspiring" because of its significance to the narrative of the apparitions. Walking through the Grotto and touching the rock is a standard part of the pilgrimage script:

Pilgrims queue (sometimes for 40 minutes to an hour in the peak summer months) outside the Grotto to access what is viewed in Lourdes etymology as the most sacred part of the Sanctuary. In the interior part of the Grotto tonight as I watch pilgrims conduct the ritualistic walk through, emotionally at times pleadingly laying their hands on the rock, I realize that the interior cave at Lourdes is the biggest worry stone in the world. The surface of the rock, now smooth, represents the collective sharing of worry, pain, trials, and troubles since the apparitions of 1858 with the murmur of sobs, praying, and pleading palpable" (field-note extract written at the Grotto, Easter 2012). 
The field-note captures the multisensory and embodied nature of this ritual, particularly in terms of sound and touch. Given the crowds at Lourdes, the need for discipline and control is inevitable (Bryman 2004). This ritual is overseen by volunteers whose scripted interactions with pilgrims reprimand transgression from the decorum of silence. As a result, the murmurs of sobs and pleas are particularly noticeable. This extra-discursive aspect of the Grotto is reminiscent of Harrison's (2007) suggestion that suffering unravels language. Scott et al. $(2016,18)$ similarly reveal that physical pain can manifest in "shrieking and shouting" but whilst they focus on self-erasure, we centralize the anxieties of daily life. The Grotto ritual is reminiscent of Sherry and Kozinets' $(2007,132)$ discussion of the cathartic benefits of “deep inscription" as pilgrims transfer their worries to the surface of the rock. We illuminate the role of touch in this ritual. In continuing the historic practice that stems from the apparitions, pilgrims' tactile explorations of the surface of the rock is core to this ritual and in keeping with its non-representational quality. Given their belief that the Grotto is contaminated with sacredness (Belk et al. 1989), this ritual offers pilgrims a route to their divine.

Therapeutic release at Lourdes occurs not only during the religious rituals but also during social time in the marketplace. Andrea, a doctor who has volunteered for many years, believes "the social side of Lourdes to have just as many healing properties as the religious Sanctuary itself for people will often talk through their worries and problems in these spaces, in the cafes, the bars, the restaurants, even the hotel" (field-note extract documenting a recorded conversation, July 2012). The commercial marketplace affords many opportunities for social interaction and field-notes are filled with examples of the sharing of confidences. Table 3 for instance includes examples of illness, grief, and relationship troubles. The sharing of confidences in Lourdes is a therapeutic activity because of the restorative emotion scripts 
that catalyze emotional unburdening. Confidences shared relate to uncontrollable life experiences and even topics that are particularly sensitive are not off limits:

I met Carol for a beer. She spoke a lot about her daughter's recent suicide and how she has discovered the reason behind it. She found out that her daughter was raped. She was upset and I was going to change the subject but she said "it helps" to talk to someone (field-note, June 2010).

Through accessing an alternative emotional geography where socio-spatial features are conducive to a "safe breakdown," our respondents share their hurts and anxieties. The main purpose of exposing suffering is to facilitate closure (Illouz 2003). Whilst Carol is still grieving the loss of her daughter, she appreciates the emotional benefits from speaking to others in Lourdes, reinforcing how emotion shifts accompany therapeutic release.

Therapeutic Renewal. Therapeutic renewal is defined as restorative benefits and improved emotional well-being through the generation of positive emotional reserves. Lisa shared the renewing quality offered by Lourdes in addressing her mental health illness, "you put your heart and soul into it but you get everything back. I come back from that week able to deal with things easier." Lisa's words illustrate how Lourdes can placate the emotional challenges she faces in daily life. This recharging comes through participation in the religious rituals associated with the Sanctuary. For example Anne describes her first experience of the Baths:

"I walked out of the Baths and my friend came bounding towards me and said, "how did you get on?" I must have only been about 16, it was my first trip to Lourdes with 
the youth group, and I said "it was good" and she gave me a hug and then I cried. I cried so hard, I don't think I have ever cried so hard in my life... I cried in a way that I have never cried before or since, it was a real cleansing cry and I remember that very vividly... it was like water washing over me simply, but the water was actually coming from inside me and it was a deeply cleansing thing" (Anne).

As mentioned earlier, water is one of the five symbols of Lourdes (see table 2). The symbolism of water stems from the Christian ritual of Baptism, which is believed to be a "rebirth" from "old identities and lives" (Strang 2006, 92). Unlike the spectacularization of water rituals in other religious sevicescapes (Crockett and Davis 2016), the Lourdes Bath ritual is private and only witnessed by two volunteers who submerge pilgrims in a small concrete tub of cold Lourdes water. The sensory shock that comes with such immersion intensifies the emotion associated with this embodied ritual. The "deeply cleansing" nature of Anne's tears is suggestive of the sense of renewal that accompanies the Baths due her belief in Lourdes water possessing spiritual and ethereal energy. Lutz $(1999,23)$ suggests that tears can "wash away" emotional suffering and Anne's link between physical immersion in the Bath and the emotional expression of tears reinforces how this therapeutic ritual is regarded as nourishing and sustaining. Similar to Strang $(2006,98)$ who finds that water rituals "give access to the distant past as well as the future," ritual bathing at Lourdes both reflects the continuity of historic practice from the time of the apparitions and signifies regeneration and therapeutic renewal.

Despite its renewing qualities, the intensity of the Sanctuary rituals are described as "wrecking" in that they can become emotionally overwhelming. As shared by Christine, "the emotion and the belief, it was so draining." On these occasions the marketplace is an important source of therapeutic renewal through the provision of "light-hearted relief:" 
“A lot of it is really quite intense emotionally and spiritually, it's all really intense. And I think part of the thing about going out into the town-we pass the shops to go back to our hotel-and I think it can be good inasmuch as it can kind of give you some light-hearted relief. It can help. As good as I think the intense experience is, I think having that all the time, like, purely for a week, would drive you crazy. I think you would just be a wreck" (Matthew).

Matthew points to the unsustainable nature of "intense" emotion. The sharp contrast between the emotional norms at Lourdes and those in respondents' home environments means that they are unaccustomed to continual heightened emotion. Thus while pilgrims welcome the therapeutic release and renewal associated with restorative emotion scripts, they also need to manage these processes so that they do not become overpowering.

The marketplace at Lourdes affords many opportunities for renewal, from sightseeing tours around the local area, to entertainment within the bars and restaurants. Many shared their enjoyment of the resounding sounds of "laughter" and the sense of "excitement" offered by the bars and cafes with the "unholy bits, singsongs in the cafes, the company, the craic [chat], just the fun of it" being what Marie remembers most from her first visit to Lourdes. Field-notes capture these "singsongs" with renditions of Oasis' Roll With It and REM's Shiny Happy People interspersed with hymns such as Ave Maria and Shine Jesus Shine (see figures 4 and 5). The uplifting emotions generated through informal socializing offers restorative benefits through the building of positive emotional reserves that become a "coping arsenal" (Frederickson and Joiner 2002, 175) when re-entering the intensity of the Sanctuary rituals: 
Veronica: "it is good taking a day away from the intensity of Lourdes Sanctuary" [discussing a day trip]

James: "yeah, it is good to move out, a brief time away from Lourdes just to let your emotions settle down a bit."

Veronica: "when you are socializing at night in all the cafes, you feel that same sense, the whole feeling of renewing yourself. It [the Sanctuary] can feel emotionally, spiritually, and sometimes even physically intense so you feel you are ready to start again the next morning."

"For years now I have set a treasure hunt for my pilgrimage groups. I set them tasks to go out into the shops in Lourdes and find me the kitsch objects; you know the sparkling Our Lady's and that? The shops are great fun, for me they are relaxing and small tasks like my annual treasure hunt, it helps you break free from the intense emotions you experience. You can temporarily switch off and that helps you to get back into it again" (Phillip).

Pilgrims' movement between the Sanctuary and the marketplace is reminiscent of Morinis's (1992) poles of "Familiar" and "Other". The Sanctuary is regarded as "Other" because of the inexplicable nature of the Sacred, whilst the marketplace is regarded as "Familiar" because of the ubiquitous presence of consumer culture. The movement between the Sanctuary and the marketplace thus becomes an intentional emotion management strategy which enables pilgrims to balance emotional suffering and informal sociality. Much like Fredrickson and Joiner's (2002) broaden-and-build theory, the data above highlights how informal sociality broadens mindsets and builds a "sense of renewal" and resilience ahead of movement back to emotional suffering. Many respondents marry together paradoxical terms, such as 
"fungrimage" (fun and pilgrimage combined) and "Holiday with Our Lady", to reflect the range of emotions experienced during the pilgrimage and the movement between happiness and suffering. We do not wish to imply that there is a simple dichotomy of Sanctuary equals tears and marketplace equals laughter. Rather, the marketplace can be a platform for emotional suffering and at the same time a source of renewal when such emotion becomes overwhelming.

\author{
Insert figures 4 and 5 about
}

here

\title{
DISCUSSION
}

The substantive contribution of this article is the theorizing of therapeutic servicescapes where localized socio-spatial features orchestrate market-mediated performances that compensate for socio-cultural dilemmas. The therapeutic servicescape comprises three features: evocative spaces, ideological homogeneity, and restorative emotion scripts. These servicescape features catalyze the consumer rituals of therapeutic relations, therapeutic release, and therapeutic renewal. Our research offers contributions in three key areas. First, we reveal how emotions are socially and geographically orchestrated and transformed in marketplace settings. Second, we demonstrate how therapeutic ritual performances reproduce emplaced, market-mediated emotion and compensate for embodied emotional restrictions. Third, we demonstrate how the negotiation of emotional ordering guides the therapeutic dialogue between religion and the marketplace. We elaborate on these contributions below. 
Localized Market-Mediated Emotion

Although it has been recognized that emotion should be central to consumer cultural studies (Gopaldas 2014), the localized production and reproduction of emotion scripts within socio-spatial contexts is neglected. Consistent with the understanding that emotion is not a self-contained individual experience (Davidson et al. 2012), our first contribution demonstrates how emotions are socially and geographically orchestrated in marketplace settings. This answers Moisio and Beruchashvili’s (2010) call for research to explore how "marketplace arrangements cultivate emotions." Our analysis has revealed that emotions are embedded in 1) socially situated emotion scripts and 2) material features that encompass narratives about the symbolic importance of place.

We have drawn on an emotional geography perspective to explore the relational quality of emotion that situates people within social geographies of place (Bondi 2005; Davidson and Milligan 2004). In doing so, we highlight that places are not inherently emotional but, rather, emotions emerge in places through the collective reproduction of ritualized consumer performances. These performances are anchored in emotion scripts that guide localized understandings about acceptable and appropriate emotional display (Fredman 2004; Hochschild 1983; Turner and Stets 2006). Our emotional geography perspective builds on prior consumer research that has considered material geographies. Canniford and Shankar (2013, 1057) highlight the importance of material geographies in preserving cultural scripts of nature. In particular, they reveal that surfers employ practices of localism in response to social tensions. Through the territorialization of particular geographic locations, surfers enforce consensus and purge contradictions that may otherwise betray the romantic cultural scripts of nature. Localism practices include "skills, styles, interaction rituals, coastal knowledge, and, as a last resort, physical violence" (p. 1062). Our perspective provides a 
useful complement by demonstrating how localism also extends to emotional geographies. Canniford and Shankar's (2013) data implies that surfing is a scripted performance that can be healing and therapeutic, but equally can be hostile and intolerant. An appreciation of the emotion scripts associated with particular locations may help to explain how this therapeutic quality is enabled. Our perspective is helpful in demonstrating that emotions are characterized by a dynamism that means they are more readily emplaced in some sociospatial settings than others.

Our analysis illustrates that emotions are not only enabled by socio-spatial features but also transformed by them. From this perspective, dynamic interaction with particular places can change a person's subjectivity and promote well-being through emotional revitalization. This perspective aligns with Lears' (1983) compensatory thesis and we suggest that status quo is sustained through placating therapeutic rituals that make the anxieties of life more tolerable. This restorative aspect of therapeutic place can only be fully understood through reference to the broader context (Conradson 2005). A comparison between the sociospatial features of the therapeutic servicescape and the socio-spatial features of other contexts that consumers inhabit thus brings the compensatory nature of the servicescape to the center of our analysis. Our research explores how localized market-mediated emotions counterbalance for socio-spatial settings characterized by undesirable cultural conditions, emotional deficits, and social suffering. Prior research does not give significant attention to the socio-spatial comparison. For example, in their study of river rafting, Arnould and Price $(1993,24)$ point to the restorative power of nature for consumers who benefit from "getting away from it all." However, we are simply told that "“iit all” ranges from Nintendo to jobrelated stress." It is outside the scope of their study to discuss in any depth what kind of socio-spatial settings their respondents encounter beyond the wilderness servicescape. In 
demonstrating how the localized meaning of therapeutic geographies is shaped by broader socio-spatial settings, we are better able to appreciate their restorative significance.

Therapeutic Ritual Embodiment

Our focus upon therapeutic rituals that centralize emotional suffering deepens our understanding of ritualized embodiment, and prioritizes issues of affect and emotion that are not addressed in detail in prior studies. Scott et al. (2016) suggest that the ritualization of pain facilitates self-renewal through a regained consciousness of physicality and the opportunity for bodily expression that does not otherwise have an outlet. Our work provides a useful complement as we consider ritualized performances that compensate for embodied emotional restrictions. Although the pain of Tough Mudder catalyzes emotional suffering, this is accompanied by self-erasure as participants "forget everything" and escape the stresses and monotony of daily responsibilities (Scott et al. 2016). Embodied performances of escapism have also been linked to sports, clubbing, and other leisure pursuits (Arnould and Price 1993; Belk and Costa 1998, Canniford and Shankar 2013; Celsi et al. 1993; Goulding et al. 2009; Kozinets 2002; Scott et al. 2016). Whilst some of these servicescapes enable intense emotions, such as the confrontation of mortality in skydiving (Celsi et al. 1993), servicescapes that directly centralize emotional suffering are less understood.

Our analysis has uncovered various embodied rituals that are therapeutic, such as bathing in Lourdes water and the visceral response to touching the Grotto. In prioritizing a socio-spatial perspective, we have demonstrated how rituals take on an embodied significance that is specific to the pilgrimage site. This perspective is helpful because it brings issues of affect and emotion to the center of our analysis and demonstrates their role in therapeutic servicescapes. While emotions are representable through language, affect 
precedes discursive meaning (McCormack 2003). Prior work on consumer embodiment illustrates that affect moves into the realm of consciousness through linguistic metaphors (Joy and Sherry 2003). Our emphasis on performance highlights nonrepresentational aspects of embodied therapeutic rituals and indicates that it would be a mistake to limit analysis to representable and linguistic processes. Rather, affect is translated into performance through “emotional expression and embodied practice" (Foley 2011, 471). Our focus on emotional suffering is particularly apt for uncovering the dynamics between affect and emotion because "[s]uffering is language destroying" (Harrison 2007, 593). We have shown that the precognitive dimension of therapeutic rituals is orchestrated by socio-spatial features that create an atmosphere conducive to emotion shifts.

Extra-discursive aspects of embodied rituals have been revealed in prior studies, such as the intensity of pain (Scott et al. 2016), the bio-social pleasures of clubbers (Goulding et al. 2009), the somatic quality of skydiving (Celsi et al. 1993), and the phatic communion amongst surfers and skydivers (Canniford and Shankar 2013; Celsi et al. 1993). However, in these studies, nonverbal therapeutic release is associated with escapism from emotional suffering. In contrast, research on the confrontation of emotional suffering prioritizes the verbal in line with Illouz's $(2008,245)$ “verbal overshadowing.” Our focus on ritualized crying directly complements prior study of support groups, particularly Moisio and Beruchashvili's (2010) discussion of how Weightwatchers meetings are appropriate venues for emotional venting, which becomes normalized within a non-judgmental and empathetic social group. Much like sociology work that has privileged the healing properties associated with voicing stories of suffering (Frank 2013; Furedi 2004; Illouz 2003), Moisio and Beruchashvili's (2010) focus is on the cathartic benefits of emotional storytelling and emotional talk. However, the social cultivation of ritualized crying within the marketplace is beyond the conceptual focus of their article. Following our theorizing, we can further 
illuminate Moisio and Beruchashvili's (2010) findings and suggest that successful therapeutic release also catalyzes embodied expressions of emotional suffering. This ritualized crying plays an important role in compensating for emotion scripts that deter crying in other contexts. Whilst not dismissing the therapeutic release associated with verbal processes, tears often articulate the messiness of emotions more effectively than spoken language. Ritualized crying also enlists non-verbal communicative responses from others, which manifest through supportive hugs and empathetic tears. This embodied support is rooted in "collections of affective bodies and spaces" (Hill et al. 2014, 388) through which "kinetic empathy" flows (Thrift 2008, 237). These extra-discursive aspects of therapeutic rituals reinforce the performative embodiment of well-being in marketplace settings.

Therapeutic Interdependence of the Marketplace and Religion

Our analysis of the therapeutic servicescape is a useful platform for unpacking the therapeutic interdependence between marketplace and religious settings. Our perspective aligns with consumer research studies that define the relationship between religion and marketplace to be one of entwinement and inseparability (McAlexander et al. 2014; Moufahim 2013). However, these studies do not prioritize spatiality. Studies that do adopt a spatial perspective tend to depict the market and religion as opposing forces. For example, Conradson's $(2007,46)$ investigation of Christian monasteries concludes that there is value in considering how the commercial economy "impinges" upon therapeutic contexts. The choice of language around impingement is suggestive that the commercial marketplace is somehow external to therapeutic settings and may diminish or erode associated therapeutic benefits. A similar discourse is found within consumer research on pilgrimage. Scott and Maclaran $(2013,206)$ conclude that "the dissonant tone of commerce infects many pilgrimage 
experiences." Husemann et al. $(2016,3365)$ illustrate how the commercial environment "disenchants" the pilgrimage, whilst Crockett and Davis (2016) discuss the de-emphasis of consumer culture at The Holy Land Experience. Similarly, Sherry and Kozinets (2007) link therapeutic and spiritual performances with temporary escape from market logic. The prioritization of the sacred-secular dichotomy overshadows the therapeutic properties of the marketplace. The adoption of this dialectical lens results in a romanticized view of pilgrimage that is no longer consistent with contemporary consumer culture. We refute the notion that the commercial marketplace "impinges" upon, "infects," or "disenchants" the pilgrimage servicescape, and, our analysis of Lourdes pilgrimage helps to extend our understanding of how therapeutic performances can be market-mediated within religious contexts.

From a social economies perspective, David Haddorff (2000) suggests an economic interdependence of religious and marketplace institutions. Similarly, in our study we find evidence of an "industry of healing" (Illouz 2003, 152) in both the Sanctuary and the marketplace. In the Sanctuary this is evident through the donations for therapeutic rituals, whilst in the marketplace this manifests in commercial and tourism activity. We build on Haddorff (2000) and suggest that the market and religion are not only economically but also therapeutically interdependent. Haddorff (2000) emphasizes that the negotiation of moral ordering guides the economic dialogue between religion and the market. We show that the negotiation of emotional ordering guides the therapeutic dialogue between religion and the market. Therapeutic interdependence stems from the back and forth movement between the Sanctuary and the marketplace which becomes an intentional emotion management strategy. In recognizing the multiple meanings and constructions of space within the therapeutic servicescape, we are able to unpack the ways that consumers create routes to well-being. Prior studies often collapse meanings and constructions of space onto one level. For example, in O'Guinn and Belk's $(1989,237)$ study on Heritage Village, religion and the commercial 
marketplace have become interpenetrated to the extent that they are "forged into a single ethos." The utopian atmosphere of Heritage Village is such that consumers detach from their daily anxieties and are expected to embrace an ethos of happiness. In contrast, in the case of the Lourdes therapeutic servicescape, emotions are not bound to a single ethos, rather consumers fluctuate between happiness and suffering. We demonstrate the role of space in orchestrating these different emotions. Drawing on Morinis (1992), the Sanctuary is perceived as "Other" due to its ethereal and divine qualities. The intensity of localized emotions in the Sanctuary pushes consumers to the marketplace for respite and the generation of positive emotional reserves. The marketplace is "Familiar" due to its human and mundane qualities. However, the familiarity of the commercial marketplace is disrupted within the therapeutic servicescape where socio-spatial features are discrepant from consumers' habitual environments. The commercial marketplace, therefore, has the dual role of enabling emotional release but also renewing consumers when emotions become overwhelming. In short, the dialogical relationship between religion and marketplace within the therapeutic servicescape orchestrates emotional ordering and consumer well-being.

\section{FUTURE DIRECTIONS}

We believe that our theorization of a therapeutic servicescape is broadly applicable to a range of consumption settings. We encourage future research to engage with the entire theorization of therapeutic servicescapes (figure 2) but also recognize that some studies may relate more with specific subordinate concepts (such as evocative spaces, therapeutic renewal etc.). The world's markets are full of various types of therapeutic servicescapes and, although different from our context, their consumer value is nonetheless explained by our theorization. For example, we have referred to the therapeutic potential stemming from the socio-spatial 
dimensions of festivals (Sherry and Kozinets 2007), fitness events (Scott et al. 2016), support groups (Moisio and Beruchashvili 2010; Tian et al. 2014), and consumer interaction with nature (Arnould and Price 1993; Canniford and Shankar 2013). Other examples which may encompass the therapeutic servicescape features and consumer rituals include consumer conventions such as Comic-Con (convention that celebrates comics and related art forms), BronyCon (convention for male fans of the My Little Pony franchise), and Goth festivals. These contexts provide the opportunity for like-minded consumers to come together in a specialized, judgement free environment where they can interact and express their identities, free from the stigma that they may otherwise encounter in their daily lives. What distinguishes our article from these other contexts is our focus on emotional suffering. Given the significant cultural differences surrounding crying in public settings (Vingerhoets 2013), future research could consider how consumers from different cultural backgrounds experience the therapeutic servicescape. For example, how do consumers from more open and tolerant emotion cultures experience therapeutic servicescapes? We also encourage future research to consider further forms of localized emotion such as anger. For example, how does the consideration of displays of anger transform our conceptualization of the socio-spatial dynamics that unfold in therapeutic servicescapes?

Future research should also consider the interdependence between religion and the marketplace in other pilgrimage settings. Coningham (2016) suggests that pilgrimage is the fastest growing motivation for travel. In particular, he profiles South Asia where the creation of various pilgrimage circuits that aim to increase religious tourism are under development. For example, recent development plans have focused on the pilgrimage site of Lumbini, the birthplace of Lord Buddha, to accommodate increasing numbers of pilgrims. Consumer researchers could explore the dialogue between religion and the marketplace within these 
South Asian contexts, and in what ways new commercial developments do (or do not) enhance sacred space. 


\section{DATA COLLECTION INFORMATION}

The first author conducted all the in-person fieldwork from 2010 until 2013. Data collection took place in both the Sanctuary of Lourdes and in Scotland, UK. Data were discussed and analyzed by both authors on a monthly basis using the first author's researcher diary, field-notes, visuals, and interview transcripts. The final ethnography was jointly authored. 


\section{REFERENCES}

Arnould, Eric J. and Linda L. Price (1993), "River Magic: Extraordinary Experience and the Extended Service Encounter,”Journal of Consumer Research, 20 (June), 24-44.

Arnould, Eric J., Linda L. Price, and Patrick Tierney (1998), “Communicative Staging of the Wilderness Servicescape,” The Service Industries Journal, 18 (3), 90-115.

Arsel, Zeynep and Craig J. Thompson (2010), "Demythologizing consumption practices: How consumers protect their field-dependent identity investments from devaluing marketplace myths," Journal of Consumer Research, 37 (5), 791-806.

Bauman, Zygmunt. (2007), Consuming Life, Cambridge, Polity Press.

Belk, Russell W. and Janeen A. Costa (1998), “The mountain man myth: A contemporary consuming fantasy," Journal of Consumer Research, 25 (3), 218-40.

Belk, Russell W., Melanie Wallendorf, and John F. Sherry Jr. (1989), “The Sacred and the Profane in Consumer Behaviour: Theodicy on the Odyssey,"Journal of Consumer Research, $16(1), 1-38$.

Bitner, Mary J. (1992), “Servicescapes: The Impact of Physical Surroundings on Customers and Employees," Journal of Marketing, 56 (2), 57-71.

Bonanno, George A., Laura Goorin, and Karin G. Coifman (2008), “Sadness and grief” in Handbook of Emotions, ed. Michael Lewis, Jeannette M. Haviland-Jones and Lisa F. Barrett, New York, The Guilford Press, 797-806.

Bondi, Liz (2005), "Making connections and thinking through emotions: between geography and psychotherapy," Transactions of the Institute of British Geographers, 30 (4), 433-48.

Brewer, John D. (2000), Ethnography, Philadelphia. Open University Press.

Bryman, Alan. (2004), The Disneyization of Society, London, Sage. 
Campbell, Colin (2005), The romantic ethic and the spirit of modern consumerism, London, WritersPrintShop.

Canniford, Robin and Avi Shankar (2013), "Purifying Practices: How Consumers Assemble Romantic Experiences of Nature,” Journal of Consumer Research, 39 (February), 1051-69.

Celsi, Richard L., Randall L. Rose, and Thomas W. Leigh. (1993), "Exploration of Leisure Consumption through Skydiving," Journal of Consumer Research, 20 (1), 1-23.

Coningham, Robin (2016), "Social and Economic Impacts of Pilgrimage in South Asia", https://www.dur.ac.uk/cech/unescochair/workshops/pilgrimage/

Conradson, David (2005), "Landscape, Care and the Relational Self: Therapeutic Encounters in Rural England," Health and Place, 11 (4), 337-48. (2007), “The Experiential Economy of Stillness: Places of Retreat in Contemporary Britain” in Therapeutic Landscapes ed. Allison Williams, Hampshire, England, Ashgate, 33-48.

Coskuner-Balli, Gokcen and Craig J. Thompson (2013), "The Status Costs of Subordinate Cultural Capital: At-Home Fathers' Collective Pursuit of Cultural Legitimacy through Capitalizing Consumption Practices," Journal of Consumer Research, 40 (June), 19-41. Craig, Carol (2004), The Scots' Crisis of Confidence, Argyll, Argyll Publications.

Crockett, David and Lenita Davis (2016), “Commercial mythmaking at the Holy Land Experience," Consumption Markets \& Culture, 19 (2), 206-27.

Dahlberg, Andrea (2013), “The Body as a Principle of Holism: Three Pilgrimages” in Contesting the Sacred: The Anthropology of Christian Pilgrimage, ed. John Eade and Michael J. Sallnow, Eugene, Oregon, Wipf and Stock Publishers, 30-50.

Davidson, Joyce, Liz Bondi, and Mick Smith (2012), Emotional Geographies, Hampshire, Ashgate Publishing, Ltd. 
Davidson, Joyce and Christine Milligan (2004), "Embodying emotion sensing space: introducing emotional geographies," Social \& Cultural Geography, 5 (4), 523-32.

Eade, John (1992), "Pilgrimage and Tourism at Lourdes, France," Annals of Tourism Research, $19(1), 18-32$.

(2013), "Introduction to the Illinois Paperback" in Contesting the Sacred: The Anthropology of Christian Pilgrimage, ed. John Eade and Michael J. Sallnow, Eugene, Oregon, Wipf and Stock Publishers, iv-xxvii.

Fargues, Cyril (2011), Lourdes, MSM Publications, Ireland.

Foley, Ronan (2011), "Performing health in place: The holy well as a therapeutic assemblage," Health \& Place, 17 (2), 470-79.

Frank, Arthur (2013), The Wounded Storyteller: Body, Illness \& Ethics, Chicago, University of Chicago Press.

Frank. Jerome D. and Julia B. Frank (1993), Persuasion and Healing: A Comparative Study of Psychotherapy, Baltimore, John Hopkins University Press.

Fredman, Glenda (2004), Transforming Emotion: Conversations in Counselling and Psychotherapy, London, Whurr Publishers.

Fredrickson, Barbara L. and Thomas Joiner (2002), "Positive emotions trigger upward spirals toward emotional well-being," Psychological Science, 13 (2), 72-5.

Furedi, Frank (2004), Therapy Culture, London, Routledge.

Gesler, Wilbert. M. (1992), “Therapeutic Landscapes: Medical Issues in Light of the New Cultural Geography," Social Science \& Medicine, 34 (7), 735-46. (2003), Healing Places, Oxford, Rowman and Littlefield Publishers, Inc.

Golpaldas, Ahir (2014), “Marketplace Sentiments,” Journal of Consumer Research, 41 (December), 995-1014. 
Goulding, Christina, Avi Shankar, Richard Elliott, and Robin Canniford (2009), “The Marketplace Management of Illicit Pleasure,” Journal of Consumer Research, 35 (5), 759-71.

Gummesson, Evert (1991), Qualitative Methods in Management Research, London, Sage.

Haddorff, David W. (2000), "Religion and the Market: Opposition, Absorption, or Ambiguity?," Review of Social Economy, 58 (4), 483-504.

Harrison, Paul (2007), ““"How shall I say it...?” Relating the nonrelational,” Environment and Planning A, 39 (3), 590-608.

Hill, Tim, Robin Canniford, and Joeri Mol (2014), "Non-representational marketing theory," Marketing Theory, 14 (4), 377-94.

Hochschild, Arlie R. (1983), The Managed Heart: Commercialization of Human Feeling, London, Routledge.

Holt, Douglas B. and Craig J. Thompson (2004), "Man-of-Action Heroes: The Pursuit of Heroic Masculinity in Everyday Consumption,” Journal of Consumer Research, 31 (September), 425-40.

Hung, Iris W. and Anirban Mukhopadhyay (2012), “Lenses of the Heart: How Actors' and Observers' Perspectives Influence Emotional Experiences," Journal of Consumer Research, 38 (6), 1103-115.

Husemann, Katharina C., Giana M. Eckhardt, Reinhard Grohs, and Raluca E. Saceanu (2016), "The dynamic interplay between structure, anastructure and antistructure in extraordinary experiences,” Journal of Business Research, 69 (9), 3361-370.

Illouz, Eva (2003), Oprah Winfrey and the Glamour of Misery: An Essay on Popular Culture, New York, Columbia University Press. (2007), Cold Intimacies: The Making of Emotional Capitalism, Cambridge, Polity Press. 
(2008), Saving the Modern Soul: Therapy, Emotions, and the Culture of Self-

help, London, University of California Press.

Joy, Annamma and John F. Sherry (2003), "Embodied Imagination: A Multisensory Approach to Understanding Aesthetic Experience," Journal of Consumer Research, 30 (1), 259-82.

Kottler, Jeffrey A. (1996), The Language of Tears, San Francisco, Jossey-Bass.

Kozinets, Robert V. (2002), “Can Consumers Escape the Market? Emancipatory Illuminations from Burning Man,” Journal of Consumer Research, 29 (1), 20-38.

Lauretin, Rene (1994), Pilgrimages, Sanctuaries, Icons, Apparitions: An Historical and Scriptural Account, UK, The Riehle Foundation.

Lears, T.J.Jackson (1983), "From salvation to self-realization: advertising and the therapeutic roots of the consumer culture, 1880-1930", in The Culture of Consumption: Critical Essays in American History, 1880-1980 ed. Richard W. Fox and T.J. Jackson Lears, New York, Pantheon Books, 1-38.

Lutz, Tom (1999), Crying: The Natural and Cultural History of Tears: A Natural and Cultural History of Tears, New York, W.W. Norton and Company.

McAlexander, James H., Beth L. Dufault, Diane M. Martin, and John W. Schouten (2014), “The Marketization of Religion: Field, Capital and Consumer Identity," Journal of Consumer Research, 41 (3), 858-75.

McCormack, Derek P. (2003), “An event of geographical ethics in spaces of affect,” Transactions of the Institute of British Geographers, 28 (4), 488-507.

McCracken, Grant (1988), The Long Interview, London, Sage University Press.

Moisio, Risto and Mariam Beruchashvili (2010), “Questing for Well-being at Weight Watchers: The Role of the Spiritual-Therapeutic Model in a Support Group," Journal of Consumer Research, 36 (February), 857-75. 
Morinis, Alan (1992), Sacred Journeys: The Anthropology of Pilgrimage, Westport, CT, Greenwood Press.

Moufahim, Mona (2013), "Religious Gift Giving: An ethnographic account of a Muslim Pilgrimage," Marketing Theory, 13 (4), 421-41.

O'Guinn, Thomas C. and Russell W. Belk. (1989), “Heaven on Earth: Consumption at Heritage Village, USA,” Journal of Consumer Research, 16 (2), 227-38.

Phipps, Marcus and Julie L. Ozanne (2017), “Routines Disrupted: Reestablishing Security through Practice Alignment," Journal of Consumer Research, 44 (2), 361-80.

Reader, Ian (2014), Pilgrimage in the Marketplace, London, Routledge.

Rook, Dennis W. (1985), “The ritual dimension of consumer behaviour,” Journal of Consumer Research, 12 (3), 251-64.

Scott, Rebecca, Julien Cayla, and Bernard Cova (2017), "Selling Pain to the Saturated Self," Journal of Consumer Research, 44 (1), 22-43.

Scott, Linda and Pauline Maclaren (2013), "Consuming the Mists and Myths of Avalon: A Case Study of Pilgrimage in Glastonbury" in Consumption and Spirituality ed. Diego Rinallo, Linda Scott, and Pauline Maclaren, London. Routledge, 195-207.

Sherry, John F. (1998), Servicescapes: The Concept of Place in Contemporary Markets, Chicago, American Marketing Association.

Sherry, John F. and Robert V. Kozinets (2007), "Comedy of the commons: Nomadic spirituality and the Burning Man festival" in Consumer Culture Theory (Research in Consumer Behavior, Volume 11), ed. Russell W. Belk and John F. Sherry, Emerald Group Publishing Limited, 119-47.

Strang, Veronica (2006), The Meaning of Water, Oxford, Berg Publishers.

Stenbacka, Caroline (2001), “Qualitative Research Requires Quality Concepts of Its Own,” Management Decision, 39 (7), 551-56. 
Thompson, Craig J. (1997), “Interpreting Consumers: A Hermeneutical Framework for Deriving Marketing Insights from the Texts of Consumers' Consumption Stories," Journal of Marketing Research, 34 (November), 438-55.

Thompson, Craig J., Howard R. Pollio, and William B. Locander (1994), “The Spoken and the Unspoken: A Hermeneutic Approach to Understanding the Cultural Viewpoints that Underlie Consumers' Expressed Meanings," Journal of Consumer Research, 21 (3), 432-52.

Thompson, Craig J. and Tuba Ustuner (2015), "Women Skating on the edge: Marketplace Performances as Ideological Edgework," Journal of Consumer Research, 42 (2), 235-65. Thrift, Nigel (2008), Non-representational Theory: Space, Politics, Affect, Routledge, London. Tian, Kelly, Pookie Sautter, Derek Fisher, Sarah Fischbach, Cuauhtemoc Luna-Nevarez, Kevin Boberg, Jim Kroger, and Richard Vann (2014), “Transforming Health Care: Empowering Therapeutic Communities through Technology-Enhanced Narratives," Journal of Consumer Research, 41 (August), 237-60.

Tumbat, Gulner and Russell W. Belk (2011), "Marketplace Tensions in Extraordinary Experiences," Journal of Consumer Research, 38 (1), 42-61. (2013), “Co-Construction and performancescapes,” Journal of Consumer Behaviour, 12 (1), 49-59.

Turner, Jonathan H. and Jan E. Stets (2006), “Sociological theories of human emotions,” Annual Review of Sociology, 32, 25-52.

Turner, Victor and Edith L.B. Turner (1978), Image \& Pilgrimage in Christian Culture, New York, Columbia University Press.

Vingerhoets, Ad (2013), Why Only Humans Weep: Unravelling the mysteries of tears, Oxford, Oxford University Press. 
Wallendorf, Melanie and Russell W. Belk (1989), “Assessing Trustworthiness in Naturalistic Consumer Research" in Interpretive Consumer Research, ed. Elizabeth C. Hirschman, Minnesota, Association for Consumer Research, 69-84.

Weinberger, Michelle F. (2015), “Dominant consumption rituals and Intragroup Boundary Work: How Non-Celebrants Mange Conflicting Relational and identity Goals,” Journal of Consumer Research, 42 (3), 1-23.

Williams, Allison (2002), “Changing geographies of care: employing the concept of therapeutic landscapes as a framework in examining home space," Social Science \& Medicine, 55 (1), $141-54$.

Wong, Nancy and Tracey King (2007), “The cultural construction of risk understandings through illness narratives," Journal of Consumer Research, 34 (5), 579-94. 
Table 1: Respondent Profiles

\begin{tabular}{|c|c|c|c|c|c|}
\hline Name & Age & Nationality & Occupation & $\begin{array}{l}\text { No of times to } \\
\text { Lourdes }\end{array}$ & Religion \\
\hline Danielle & 18 & Scottish & Student & 1 & Catholicism \\
\hline Frances & 17 & Scottish & Student & 1 & Catholicism \\
\hline Brendan & 73 & Irish & Priest & $\begin{array}{l}\text { Lives in } \\
\text { Lourdes }\end{array}$ & Catholicism \\
\hline Kelly & 35 & Scottish & $\begin{array}{l}\text { Secondary school } \\
\text { teacher }\end{array}$ & 6 & Catholicism \\
\hline Lisa & 19 & Scottish & Student & 5 & Catholicism \\
\hline Lilly & 24 & Scottish & Primary school teacher & 7 & Catholicism \\
\hline Miriam & 25 & Scottish & Marketing Assistant & 11 & Catholicism \\
\hline Matthew & 22 & Scottish & Student & 5 & Catholicism \\
\hline Marie & 54 & Scottish & Historian & $50+$ & Catholicism \\
\hline Patricia & 93 & Scottish & Retired & $60+$ & Catholicism \\
\hline Paul & 63 & Scottish & $\begin{array}{l}\text { Secondary School } \\
\text { teacher }\end{array}$ & 10 & Catholicism \\
\hline Phillip & 61 & Scottish & Business man & $21+$ & Catholicism \\
\hline Pierre & 40 & French & Hotel Chain Owner & $\begin{array}{l}\text { Lourdes } \\
\text { Native }\end{array}$ & Catholicism \\
\hline Anne & 37 & Scottish & Nun & 8 & Catholicism \\
\hline Garry & 25 & Scottish & $\begin{array}{l}\text { Secondary school } \\
\text { teacher }\end{array}$ & 6 & Catholicism \\
\hline Jacob & 27 & Scottish & $\begin{array}{l}\text { Primary School } \\
\text { teacher }\end{array}$ & 12 & Catholicism \\
\hline Veronica & 60 & Scottish & Retired & 11 & Catholicism \\
\hline James & 63 & Scottish & Doctor & 11 & Catholicism \\
\hline Christine & 63 & Scottish & Retired & 13 & Catholicism \\
\hline Kitty & 66 & Scottish & Retired & 10 & Catholicism \\
\hline Rachael & 74 & Scottish & Retired & 10 & Catholicism \\
\hline Iris & 67 & Scottish & Retired & 8 & Episcopalian \\
\hline Yasmina & 27 & French & Researcher & 1 & Spiritual \\
\hline
\end{tabular}


Table 2: The Symbols of Lourdes (based on http://en.lourdes-france.org/deepen/the-signs-of-lourdes).

\begin{tabular}{|c|c|c|c|}
\hline Symbol & Link to Lourdes narrative & Photo & Examples of therapeutic rituals \\
\hline $\begin{array}{l}\text { The } \\
\text { rock }\end{array}$ & $\begin{array}{l}\text { The Grotto of Massabielle upon which Our Lady is } \\
\text { believed to have appeared during the } 1858 \\
\text { apparitions. Touching the rock symbolizes "the } \\
\text { embrace of God, solid as a rock." }\end{array}$ & & Walking through and touching the rock. \\
\hline $\begin{array}{l}\text { The } \\
\text { water }\end{array}$ & $\begin{array}{l}\text { Water flows at the Grotto from the River Gave. } \\
\text { This water source was discovered by Bernadette } \\
\text { during an apparition when she was directed to } \\
\text { consume muddy and dirty water that gradually } \\
\text { became clear. For Catholics, this is symbolic of } \\
\text { the sinful state of the human condition that is } \\
\text { cleansed through prayer and penance. Plastic } \\
\text { bottles are sold for transporting Lourdes water } \\
\text { home (see image). }\end{array}$ & & $\begin{array}{l}\text { The Baths involve immersion in } \\
\text { Lourdes water. }\end{array}$ \\
\hline $\begin{array}{l}\text { The } \\
\text { light }\end{array}$ & $\begin{array}{l}\text { Light stems from the } 700-800 \text { tonnes of candles } \\
\text { burned annually at Lourdes. During one of the } \\
\text { apparitions Bernadette was holding a burning } \\
\text { candle which Our Lady asked her to leave in the } \\
\text { Grotto. Candles provide Catholics a tangible way } \\
\text { to symbolize their hope in Jesus as the light of the } \\
\text { world. }\end{array}$ & & $\begin{array}{l}\text { During the evening torchlight } \\
\text { procession, pilgrims each carry a } \\
\text { candle whilst walking and praying } \\
\text { together. }\end{array}$ \\
\hline
\end{tabular}




\begin{tabular}{|l|l|l|l|}
\hline $\begin{array}{l}\text { The } \\
\text { crowds }\end{array}$ & $\begin{array}{l}\text { During the apparitions people travelled from the } \\
\text { surrounding countryside to the pilgrimage site. } \\
\text { Since the official recognition of the apparitions by } \\
\text { the Catholic Church in 1862, local and } \\
\text { international pilgrimages have become } \\
\text { increasingly popular. }\end{array}$ & $\begin{array}{l}\text { Religious services and processions } \\
\text { when different nationalities congregate } \\
\text { for religious fellowship. }\end{array}$ \\
\hline $\begin{array}{l}\text { The } \\
\text { sick }\end{array}$ & $\begin{array}{l}\text { The first miracle of Lourdes occurred during an } \\
\text { apparition when a woman's dislocated arm was } \\
\text { healed when submerged in the Lourdes water. } \\
80,000 \text { sick and disabled people visit Lourdes } \\
\text { each year in search of healing. Sick pilgrims are } \\
\text { transported around Lourdes in specially designed } \\
\text { wheelchairs called voitures (see image). }\end{array}$ & $\begin{array}{l}\text { The Anointing of the Sick is a } \\
\text { religious service when sick } \\
\text { pilgrims receive a blessing. }\end{array}$ \\
\hline
\end{tabular}


Table 3: Overview of Consumer Rituals in the Therapeutic Servicescape

\begin{tabular}{|c|c|c|c|}
\hline $\begin{array}{l}\text { Consumer } \\
\text { rituals }\end{array}$ & Definition & Sanctuary examples & Marketplace examples \\
\hline $\begin{array}{l}\text { Therapeutic } \\
\text { relations }\end{array}$ & $\begin{array}{l}\text { Relating } \\
\text { intimately } \\
\text { with trusted } \\
\text { fellow } \\
\text { consumers. }\end{array}$ & $\begin{array}{l}\text { "The experiences were far more moving because I } \\
\text { was part of a group; it was a community that was } \\
\text { experiencing all the prayer, it was a community } \\
\text { that all walked together through the torchlight } \\
\text { procession" (Kelly). } \\
\text { "Whilst working in the Baths I must have cuddled a } \\
\text { million people because they were so emotional, } \\
\text { they just needed to grab on to somebody" } \\
\text { (Christine). } \\
\text { "My niece's friend was there as a sick pilgrim, in } \\
\text { fact the doctors did not know how she was still } \\
\text { alive, she was just skin and bone. She was } \\
\text { desperate to do the High Stations [a prayer ritual]. } \\
\text { There is no way on earth she could have because } \\
\text { of the steep hill but one of the youths took her on } \\
\text { his back and took her right up and back down, he } \\
\text { would set her down when they stopped and hold } \\
\text { her steady while she prayed" (Veronica). }\end{array}$ & $\begin{array}{l}\text { "I'm thinking this summer, Cath, Mary, Ashley, Paddy, Nula, } \\
\text { and Mhairi are all coming. And this is the third time with them, } \\
\text { and I will take a day out with them and we'll socialize and have } \\
\text { a drink, and l'll write to them during the year, and we have } \\
\text { bonded, we are like a little family, and Lourdes has done that. } \\
\text { My life is richer because they are here, and their lives are } \\
\text { richer because of me, and they are not just acquaintances, and } \\
\text { that is one of the things that can happen in Lourdes, genuine } \\
\text { time with each other" (Brendan). } \\
\text { "Last year we were in the café having a drink and one of the } \\
\text { sick pilgrims who we were caring for, Nina, said "I don't want to } \\
\text { go home, I don't have any family at home" which was heart- } \\
\text { breaking to hear. And when you hear that, you kind of realize } \\
\text { how much, just spending ten minutes with a sick pilgrim, it's a } \\
\text { really big deal to them, it's huge, it's this big thing" (Matthew). }\end{array}$ \\
\hline $\begin{array}{l}\text { Therapeutic } \\
\text { release }\end{array}$ & $\begin{array}{l}\text { The } \\
\text { exposure of } \\
\text { emotional } \\
\text { suffering. }\end{array}$ & $\begin{array}{l}\text { "I like going down where the candles are lit, a } \\
\text { couple of years ago I was there and all I could } \\
\text { think about was my grandpa. He'd died what, five- } \\
\text { and-a-half years before that? And I thought I was } \\
\text { fine with it. But I really wasn't, he was all I could } \\
\text { think of and I just cried my heart out. I could not } \\
\text { stop" (Matthew). }\end{array}$ & $\begin{array}{l}\text { "It gave me the opportunity to sit and chat to people especially } \\
\text { at night in the pubs or over dinner. I felt it brought emotions out } \\
\text { that you kind of lock away, that you don't want people to know. } \\
\text { It definitely helped me with my grief. It was five years since my } \\
\text { mum died so it wasn't like it had just happened. I don't know } \\
\text { what it was, but I finally started talking about it and I'm much } \\
\text { better now" (Lilly). }\end{array}$ \\
\hline
\end{tabular}




\begin{tabular}{|c|c|c|c|}
\hline & & $\begin{array}{l}\text { "It was at the sacrament of the sick and during the } \\
\text { ceremony one of the priests came right up to me } \\
\text { and he was like "are you Jacob?" and I said "yeah" } \\
\text { and he said, "well, I've been sent over to bless } \\
\text { you" and after that I was a total wreck. I never } \\
\text { classed myself as sick or anything and I'm not sick, } \\
\text { but the fear that I could be sick again was present } \\
\text { at that point [referring to being in remission from } \\
\text { skin cancer]. I don't think I realized I was worried } \\
\text { about that until that blessing. It was unexpected } \\
\text { but completely what I needed and I was just an } \\
\text { emotional wreck after it but in a good way, you } \\
\text { know" (Jacob). }\end{array}$ & $\begin{array}{l}\text { "There was a volunteer, Alice, I didn't know her very well, but } \\
\text { she'd been talking to a young woman who had cancer. As she } \\
\text { was walking up the road she got really upset because a family } \\
\text { member was also dealing with the same illness, and it all hit } \\
\text { home to her, the reality of it. Alice explained "l've just not been } \\
\text { thinking about it but here it all comes to the surface". I just } \\
\text { stopped, gave her a big hug and let her cry it out in the middle } \\
\text { of the street with the shops, the traffic and people all buzzing } \\
\text { around us, and in Lourdes that's ok, it's normal" (Miriam). } \\
\text { In the hotel today, Sarah talked to me about her marriage. Her } \\
\text { husband has been offered a job that would mean moving } \\
\text { country which she does not want to do. She has spent her time } \\
\text { at Lourdes reflecting on what this means for their future and was } \\
\text { upset as she believes this could be the end of her marriage } \\
\text { (Field-note, July 2012). }\end{array}$ \\
\hline
\end{tabular}




\begin{tabular}{|c|c|c|c|}
\hline $\begin{array}{l}\text { Therapeutic } \\
\text { renewal }\end{array}$ & $\begin{array}{l}\text { Restorative } \\
\text { benefits and } \\
\text { improved } \\
\text { emotional } \\
\text { well-being } \\
\text { through the } \\
\text { generation } \\
\text { of positive } \\
\text { emotional } \\
\text { reserves. }\end{array}$ & $\begin{array}{l}\text { "I went to Lourdes shattered because a friend of } \\
\text { mine had really hurt me badly, it had been a bit of } \\
\text { a nightmare and I was so tired in a way that I have } \\
\text { never been before. I was actually exhausted and } \\
\text { so I certainly went out looking for rest and honestly } \\
\text { my intention was as basic as falling into the arms } \\
\text { of Our Lady. That was all I wanted. It was } \\
\text { incredibly healing and an incredible rest for me. I } \\
\text { never come back from Lourdes empty-handed, } \\
\text { there is always something and I certainly got the } \\
\text { rest that I looked for" (Anne). } \\
\text { "Oh there is a spiritual need for me to go alright, I do } \\
\text { definitely need, and I find that I get it at Lourdes, a } \\
\text { great peacefulness from Lourdes" (Patricia). }\end{array}$ & $\begin{array}{l}\text { I went to the Baths this morning, it was beautiful but I cried in a } \\
\text { way I haven't in a long time ... On writing the above, I needed } \\
\text { to stop as I felt too overwhelmed and upset. I thought a walk } \\
\text { would help and I bumped into Jolie who I volunteer with, she is } \\
\text { also off today and was heading to the Spanish border. She } \\
\text { invited me to come and when I refused she said, "you know, } \\
\text { sometimes we all need a break from whatever it is Lourdes } \\
\text { draws out of us". Before I knew it I'm on a tour, the views were } \\
\text { awesome and the sounds of the cowbells from the hills made } \\
\text { me feel so calm and refreshed (Field-note July 2011). } \\
\text { "All of us joined hands [around } 60 \text { youth group members] and } \\
\text { ran all the way towards and through the town, we must have } \\
\text { ran about half a mile and we were running through cars and it } \\
\text { was mental. People were honking their horns at us and we ran } \\
\text { through a shop as well, like we went all the way through it. It } \\
\text { was wonderful, we were just daft for } 15 \text { minutes, which allowed } \\
\text { us to escape for, just a spell, the seriousness of the } \\
\text { experience, the caring, the emotion, you know. Then after our } \\
\text { run we went back to work, back to the seriousness, but that } \\
\text { moment it helped me a lot, it freed me a little from the intensity } \\
\text { of the experience and allowed me to go on afterwards" } \\
\text { (Danielle). }\end{array}$ \\
\hline
\end{tabular}



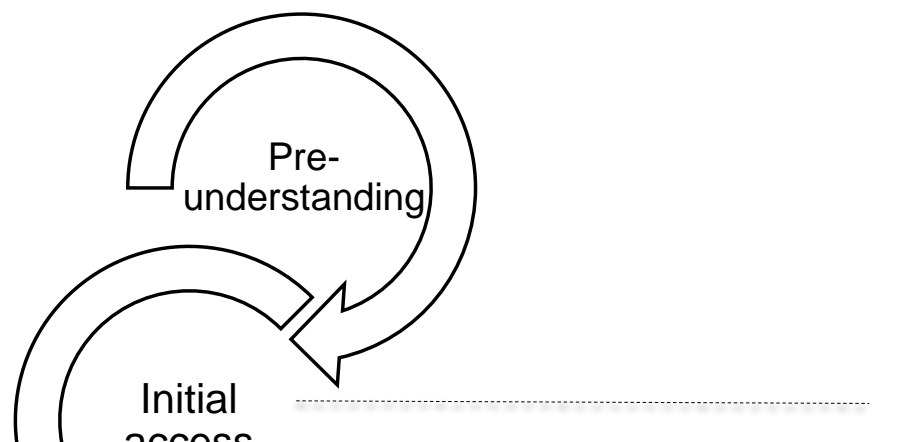

April 2011: A four day immersive fieldtrip was undertaken to better understand the site of Lourdes. This enabled networking with key gatekeepers, permitting future access to the organization and team.

June/July 2011: Three week volunteering fieldtrip with French voluntary association at Sanctuary.

April 2012: Week long fieldtrip during Christian festival of Easter.

April 2012-Early 2013: Depth interviews with Lourdes pilgrims.

June 2012: Ten day fieldtrip to Lourdes.

July 2012: Fieldtrip with regional pilgrimage group, during which researcher volunteered.

May 2013: Week long reflective fieldtrip to Lourdes. 


\section{Evocative spaces}

encompass natural, built, and symbolic environments and are defined by their capacity to bring powerful archetypes, memories, visions, and their attendant feelings to mind.
Ideological homogeneity

refers to the like-minded beliefs that provides a sense of safety and security through the convention of tolerance and acceptance of the behaviors, emotions, and beliefs of others.

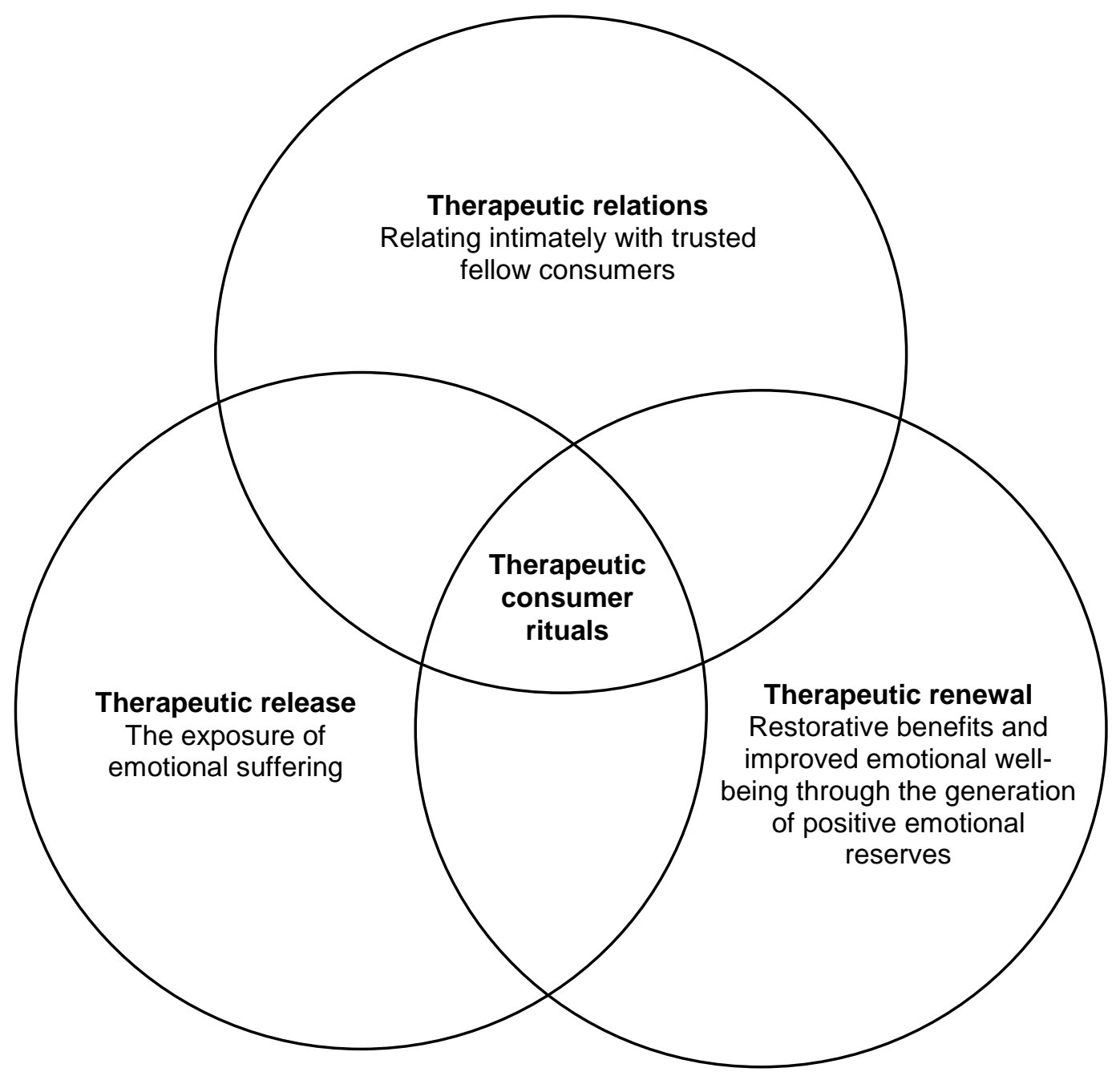

Restorative emotion scripts enable emotional release that promotes well-being. 
FIGURE 3: THE ROSARY BASILICA OF LOURDES

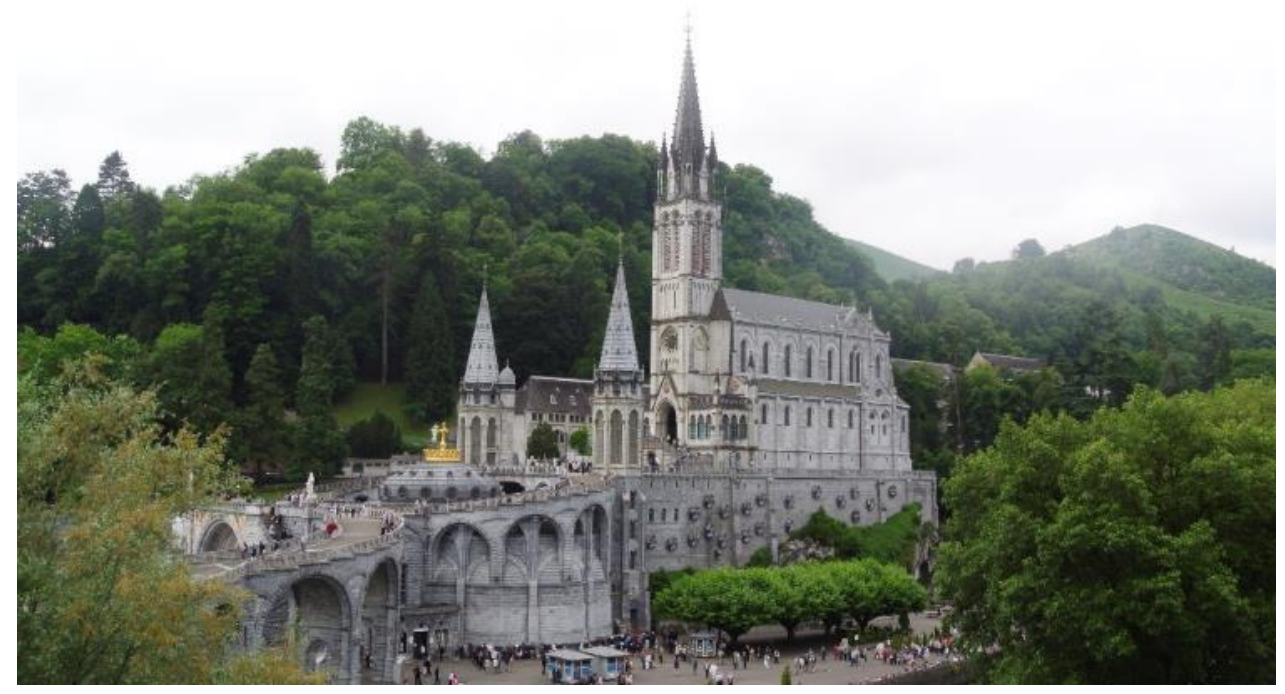


FIGURE 4: SING-SONG IN A BAR

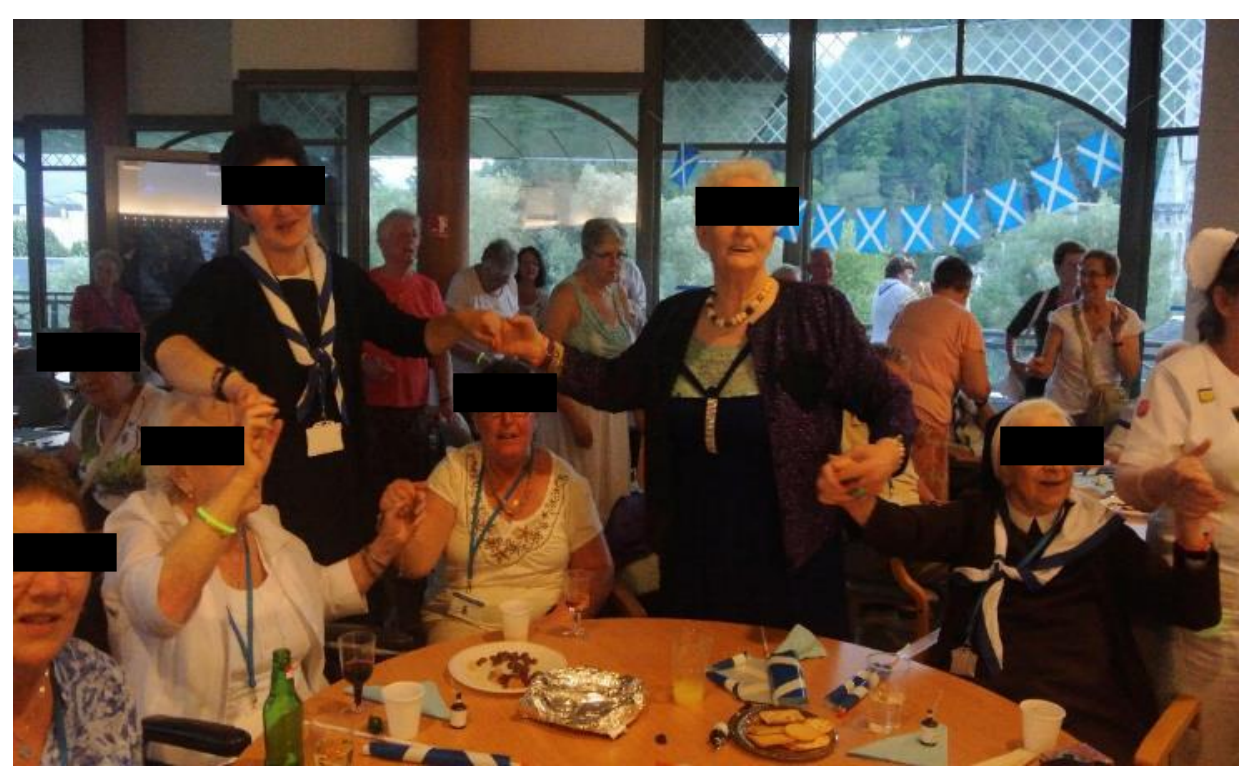


FIGURE 5: THE LAUGHER OF LOURDES

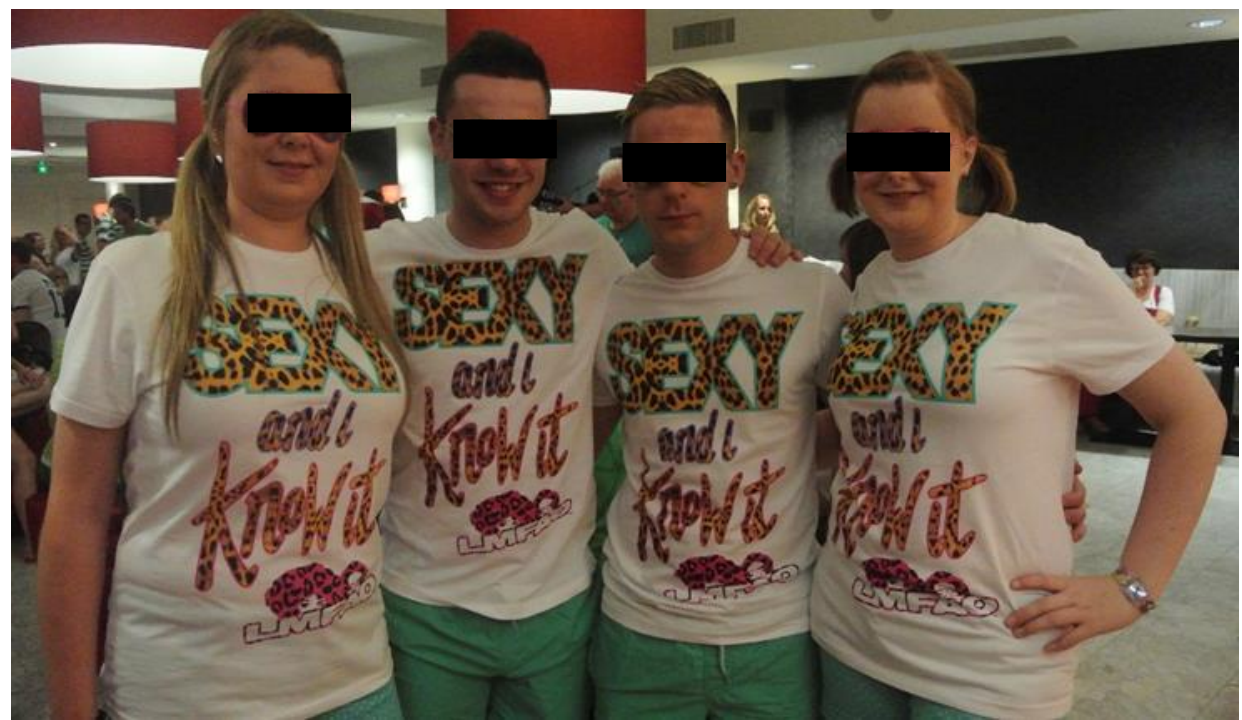


HEADINGS LIST

1) THEORETICAL FOUNDATIONS

2) Introducing Therapeutic Servicescapes

2) Theorizing Emplaced Consumer Emotion

1) RESEARCH METHODS

2) Context: Lourdes Pilgrimage

2) Data Collection

2) Data Analysis

1) FINDINGS

2) Therapeutic Servicescape Features

3) Evocative Spaces.

3) Ideological Homogeneity.

3) Restorative Emotion Scripts.

2) Therapeutic Consumer Rituals

3) Therapeutic Relations.

3) Therapeutic Release.

3) Therapeutic Renewal.

1) DISCUSSION

2) Localized Market-Mediated Emotion

2) Therapeutic Ritual Embodiment

2) Therapeutic Interdependence of the Marketplace and Religion

1) FUTURE DIRECTIONS

1) DATA COLLECTION INFORMATION

1) REFERENCES 